NBER WORKING PAPER SERIES

\title{
DO WELFARE ASSET LIMITS \\ AFFECT HOUSEHOLD SAVING? \\ EVIDENCE FROM WELFARE REFORM
}

\author{
Erik Hurst \\ James P. Ziliak \\ Working Paper 10487 \\ http://www.nber.org/papers/w10487
NATIONAL BUREAU OF ECONOMIC RESEARCH
1050 Massachusetts Avenue
Cambridge, MA 02138 \\ May 2004
}

Send comments to jziliak@uky.edu. We thank Mark Aguiar, Orazio Attanasio, Steve Davis, Gary Engelhardt, Austan Goolsbee, Craig Gundersen, Shif Gurmu, Tom Kniesner, Alana Landy, Annamaria Lusardi, Robert Moffitt, Don Oellerich, Melinda Pitts, Lucie Schmidt, Karl Scholz, Mark Schreiner, Jonathan Skinner, Tim Smeeding, Nick Souleles, Geoffrey Wallace, Aaron Yelowitz, Steve Ziliak, three anonymous referees, and seminar participants at the 2002 American Economic Association Meetings, Georgia State University, Georgia Tech University, the 2001 Institute for Research on Poverty Summer Workshop, Syracuse University, the University of Chicago, and the University of Wisconsin for helpful comments on an earlier version of this paper that circulated under the title "Welfare Reform and Household Saving." This project was supported under grant number 00ASPEE355A from the Office of the Assistant Secretary for Planning and Evaluation in the U.S. Department of Health and Human Services. The opinions and conclusions expressed herein are solely those of the authors and should not be construed as representing the opinions or policy of any agency of the Federal Government. The views expressed herein are those of the author(s) and not necessarily those of the National Bureau of Economic Research.

(C2004 by Erik Hurst and James P. Ziliak. All rights reserved. Short sections of text, not to exceed two paragraphs, may be quoted without explicit permission provided that full credit, including (C) notice, is given to the source. 
Do Welfare Asset Limits Affect Household Saving? Evidence from Welfare Reform

Erik Hurst and James P. Ziliak

NBER Working Paper No. 10487

May 2004

JEL No. E2, H2, H3, I3

\section{ABSTRACT}

In this paper, we use household-level data from the Panel Study of Income Dynamics to examine the impact of new saving incentives that were implemented as part of the overhaul of U.S. welfare policy during the mid-1990s on the saving of households at risk of entering welfare. The Temporary Assistance to Needy Families program devolved responsibility of program rules to the states, and many states have responded by relaxing liquid asset and vehicle-equity limits that determine program eligibility, and by introducing time limits on benefit receipt. According to the recent theoretical work and statements made by public officials, such policies are predicted to increase total savings for those households who have a large ex-ante probability of welfare receipt such as femaleheaded households with children. We follow a sample of female heads with children from 1994 to 2001 and find that in both absolute terms, and relative to comparison groups of male heads and female heads without children, there has been no impact of welfare policy changes on the saving of at-risk households.

Erik Hurst

University of Chicago

Graduate School of Business

1101 E. $58^{\text {th }}$ Street

Chicago, IL 60637

and NBER

erik.hurst@gsb.uchicago.edu

James P. Ziliak

University of Kentucky

335 Gatton Business and Economics Building

Lexington, KY 40506-0034

jziliak@uky.edu 


\title{
Do Welfare Asset Limits Affect Household Saving? Evidence from Welfare Reform
}

\begin{abstract}
"Mr. Chairman, the welfare system in and of itself needs radical perestroika, restructuring; radical overhaul. .... Any asset is a violation of the welfare laws. We tell the American people we want you to save. We want you to be businessmen and women. We want you to go to work. But the welfare system in this socialist economy takes away the asset, the property, and, worst of all, takes away the incentive for getting out of poverty. It's a national disgrace."

--Jack Kemp, Secretary of Housing and Urban Development, Testimony to the Joint Economic Committee Hearing on The War on Poverty, November 19, 1991.
\end{abstract}

Saving is a critical part of a household's quest for self-sufficiency. If asset markets are incomplete, savings may be the only way for a household to get a down payment for a home, educate themselves or their children, move to a different neighborhood with better schools, or smooth unforeseen contingencies such as medical emergencies or unemployment. However, it is well documented that low-income American households persistently hold little wealth (Browning and Lusardi 1996; Carney and Gale 2001; Charles and Hurst 2002; Hurst, et al. 1998; Sherraden 1991; Ziliak 2003). In 1994 over $90 \%$ of welfare recipients, over $80 \%$ of pre-retired households with children who have less than a high school education, and over $70 \%$ of preretired households with children who have just a high school education have accumulated less than $\$ 500$ in liquid assets. Nearly half of low-income families had zero liquid assets in either 1994 or $2001 .^{1}$

A long-standing question faced by economists is "Relative to their incomes, why do the poor save so little?" If low-income households are relatively more impatient than high-income households or if low-income households are more likely to have time inconsistent preferences, the difference in time preferences could explain the differences in accumulated wealth between poor and other households, conditional on income (Lawrance, 1991; Samwick, 1997; Laibson,

\footnotetext{
1 Authors' calculation using 1994 and 2001 data from the Panel Study of Income Dynamics.
} 
1997, Angeletos et al., 2001). Alternatively, by providing households with a consumption floor during times of temporary unemployment spells or subsidizing medical care when the household experiences a health shock, governmental welfare policies could reduce the household's income uncertainty and thus reduce their need to save for precautionary reasons irrespective of discount rates (Hubbard, et al., 1995; Gruber and Yelowitz, 1999; Neumark and Powers, 1998; Ziliak 2003). The high replacement rate of income provided by Social Security for low lifetimeincome households can reduce their need to save for lifecycle reasons. Aside from decreasing precautionary or lifecycle motives to save, government welfare policies may have additional direct effects on household saving incentives. In order to receive many forms of government assistance, households are required to hold liquid and vehicle assets below the federal or state mandated limits. An influential theoretical analysis by Hubbard, Skinner and Zeldes (1995) shows that such means-tested welfare programs can explain the low savings observed in the data for households with low lifetime resources.

In this paper, we formally test whether welfare asset limits serve as a deterrent to saving for poor households as suggested by the theoretical model of Hubbard, et al. (1995) and by prominent policy makers such as Secretary Kemp. We take advantage of fundamental reform to the U.S. welfare system in the mid-1990s to answer this question and to shed new light on the saving behavior of low-income families. The Personal Responsibility and Work Opportunity Reconciliation Act (PRWORA) of 1996 radically changed the delivery of cash welfare to program participants. PRWORA transformed Aid to Families with Dependent Children (AFDC) from an entitlement program that provided cash benefits to those households who satisfied state and federal eligibility standards into a work-based program called Temporary Assistance to Needy Families (TANF) that is almost exclusively controlled by the states. Funding for TANF 
is provided by a block grant from the federal government that is tied to the states AFDC expenditure level in 1992-1995, but states are able to exert great discretion over program rules.

In response to PRWORA, many states attempted to reverse the fortunes of the poor and to stimulate saving by loosening limits on liquid-asset and vehicle wealth holdings and by adopting time limits on benefit receipt, which are likely to affect precautionary motives to save. Testing the impact of these policy changes on saving is important both from a program evaluation perspective and because they provide additional evidence on the extent to which the theoretical predictions of Hubbard, et al. (1995) regarding asset limits are borne out in the data.

Using data from the Panel Study of Income Dynamics, including information from the 1994 and 2001 wealth supplements, we provide the first evidence on the extent to which saving responded to the state-level changes in asset limits associated with welfare reform. To identify the effects of the programmatic changes on saving we exploit both cross-state differences over time in policy choices as well as the fact that certain populations are more at risk of taking up welfare and thus more likely to respond to the policy reforms. Our key at-risk group is femaleheaded households with children, while the comparison groups are female heads without children and male headed households. While other components of the cash welfare system changed simultaneously, such has work requirements and earnings disregards, most of these affect saving only indirectly via the individual's earnings. Thus, our empirical model controls for both the baseline level and change in labor-market earnings, along with other measured demographics likely to affect saving.

Across a variety of model specifications we find that the saving of female-headed households with children has not responded economically or statistically to the welfare-reform induced changes in liquid-asset limits, vehicle limits, or time limits implemented as part of 
PRWORA. Focusing on households most likely to respond to welfare asset limits, we estimate the upper bound saving response of the 95 percent confidence interval to a $\$ 1000$ increase in the liquid asset limit to be $\$ 50$, while the average response across numerous specifications ranges from $-\$ 80$ to $\$ 10$. We also show that aside from potentially increasing the incidence of owning a vehicle, these changes in asset limits did not affect other measures of self sufficiency (i.e., owning a checking account, owning a home, or starting a business). We conclude that the low saving of the poor - particularly female heads with children - is not caused by welfare asset limits.

\section{Background}

TANF, like AFDC, is a means-tested program in which eligibility is determined by passing a sequence of asset tests as well as gross and net-income tests (along with the requirement that dependent children under age 18 be present in the household). After the passing of PRWORA in 1996, many states attempted to reverse the fortunes of the poor and to stimulate saving by loosening limits on liquid-asset and vehicle wealth holdings and by adopting time limits on benefit receipt, which are likely to affect precautionary motives to save. Additionally, net-income tests were also changing during this period. The income tests under AFDC were based on a state's need standard, i.e. gross income was not permitted to exceed 185 percent of the state's need standard. These income tests are no longer a requirement under federal TANF rules, and most states have altered their AFDC program rules accordingly (TANF Report to Congress 1998). ${ }^{2}$

In this section, we outline the change in liquid asset limits undertaken by the states as part of their implementation of TANF programs. We focus on the asset limits first given that it has

2 Under AFDC, two-parent families were eligible for benefits only if the children were deprived of support due to incapacitation of a parent or because of the un(under)employment of the principal wage earner. As of federal fiscal year 1998, however, 37 states treat single and two-parent households identically for eligibility purposes, 8 states retained all three original rules, and the remaining states retained some of the restrictions and/or modified the original rules (Gallagher, et al. 1998). 
received the most attention by policy makers and academics as being a cause of low saving among the poor. In Section VI, we discuss and test the impact of many of the other policy changes implemented by the states as part of the overhaul of their welfare programs. Foreshadowing the results, we find that these additional policy reforms, like asset-limit changes, have had little effect on the saving of the poor.

Historically, states were given some latitude in setting real property and vehicle asset limits used in determining benefit eligibility under AFDC. ${ }^{3}$ Indeed, prior to the Omnibus Budget Reconciliation Act of 1981, there was substantial state-specific heterogeneity in asset limits, but by 1984 only five states had vehicle limits below the allowable federal maximum of $\$ 1500$, and nine states had non-housing, non-burial personal property limits below the federal maximum of $\$ 1000$. However, by 1994 , all states but two had their asset limits set equal to the federal maximum (California and Iowa had received welfare waivers prior to 1994). Under TANF, most states have broke ranks with the more restrictive AFDC rules and have altered their asset limits. Specifically, by federal fiscal year 2001, 41 states and the District of Columbia had increased the liquid-asset limit above their previous 1994 limit of \$1000 (Gallagher, et al. 1998; TANF Report to Congress 1998, 2002). For most of these states, the published goal of increasing asset limits associated with TANF was to promote saving among low income households. In Appendix Table 1, we summarize the changes in liquid-asset and vehicle-equity limits for the typical TANF recipient relative to the previous federal maximum limit. As of 2001, nine states had kept their liquid asset limit at $\$ 1,000,22$ states increased their liquid asset limit by between $\$ 500$ and $\$ 1,000$, and the remaining 20 states increased their liquid asset limit by more than $\$ 1,000$. Ohio

\footnotetext{
3 Many AFDC/TANF recipients also receive Food Stamp benefits. However, unlike TANF, the Food Stamp Program is administered at the national level. In terms of welfare policy, AFDC/TANF imposes one set of asset limits on its recipients and the Food Stamp Program places a potentially different set of asset limits on its recipients. In a robustness section, we discuss our results when we control for the interaction of different welfare policy asset limits on household saving.
} 
is the only state to remove the liquid asset requirement. ${ }^{4}$ The heterogeneity in changes in the liquid asset limits across states will provide identification for our empirical work.

Perhaps surprisingly, there has been a paucity of research on the effect of assets limits on household saving. The survey of transfer programs by Danziger, et al. (1981) discusses the impact of social security on private saving, but not the effect of welfare programs, while the more recent income-transfer survey by Moffitt (1992) is silent altogether on the saving decision. Recently, theoretical models on the effects of means tested asset programs on household wealth accumulation preceded the empirical work. Specifically, Hubbard, et al. (1995) investigated the implications of asset-based means testing in a life-cycle simulation model of saving with earnings uncertainty and out-of-pocket medical expenditures. Their simulations suggest that because of the existence of asset limits on government sponsored welfare programs, coupled with the consumption floor of benefits, low-income households are better off by not engaging in significant saving. They concluded that means tested asset limits were an important hindrance to the saving of low income households.

To our knowledge, Powers (1998) offers the only formal empirical test of asset limits on private saving. ${ }^{5}$ She studied how changes in the net wealth of 229 female heads of household in the National Longitudinal Survey of Young Women responded to the homogenization of crossstate asset limits after passage of the Omnibus Budget Reconciliation Act of 1981. Her preferred estimate is that saving between 1978 and 1983 decreased by $\$ 0.25$ for each $\$ 1$ decrease in the asset limit in 1981. In our study, we offer new and improved estimates of the impact of asset

\footnotetext{
4 To account for the unlimited liquid asset limits, we exclude households from Ohio from our sample. Our results were not sensitive to this restriction. In fact, we found that at-risk households in Ohio were not more likely to increase liquid asset holdings between 1994 and 2001 (compare to households in other states).

${ }_{5}$ Gruber and Yelowitz (1999) also study the impact of Medicaid asset limits on private saving and find evidence consistent with Powers (1998). Their analysis is less direct than Powers (1998) because the impact of asset limits is identified off an interaction between states with asset limits and changes in Medicaid coverage. In related work, Neumark and Powers (1998) examine the effect of cross-state differences in SSI benefits (i.e. the consumption floor) on pre-retirement saving.
} 
limits on household saving; new because this is the first study to exploit the most comprehensive overhaul in welfare policy and its impact on saving; improved because we use a higher-quality survey of wealth, we implement a more precise identification strategy of policy reforms, and we examine more targeted outcomes associated with the policy reforms (e.g. liquid asset accumulation, propensity to purchase vehicles, and propensity to become a homeowner). Specifically, in our analysis, as in Powers, we focus on a group of individuals who are most likely to respond to welfare programs - female-headed households with children. Where we differ in our identification scheme relative to Powers is in our use of female-headed households with no children and male-headed households as comparison groups. ${ }^{6}$ As we discuss below, the near term incidence of welfare for these two groups in our sample was essentially zero. Lastly, we focus on a different time period - the mid 1990s - where the specific goal associated with changing welfare asset limits at the state level was to stimulate savings among low income households. In later sections, we offer some possible explanations for the difference between our results and the results of Powers.

\section{Data Description}

To examine the effects of recent welfare reform on the saving of low income households, we use data that comes from the University of Michigan's Panel Study of Income Dynamics (PSID) for the years 1994 to 2001 . The PSID began in 1968 with 4,802 households and over 18,000 individuals and by the 1994 wave had nearly 8,500 families and over 50,000 individuals. Of the initial 4,802 households, 2,930 were selected from the Survey Research Center's random sample of the U.S. population, while the remaining 1,872 families were drawn from the Survey of Economic Opportunity's sample of the low-income population. The latter sample feature

\footnotetext{
${ }^{6}$ It should be noted that our results are not driven by the use of a comparison group. Identification of asset-limit effects on saving is obtained from cross-sectional variation in asset policy. The comparison groups are simply used as an additional specification check to verify that our results are not spurious. As we show in Table 2, no matter how we cut the data, female heads with children did not respond to the change in asset limits.
} 
makes the PSID a valuable tool for the study of U.S. welfare programs. Starting in 1968, the PSID has re-interviewed individuals from those households every year-adults have been followed as they have grown older, and children have been observed as they advance through childhood and into adulthood. The main focus of the PSID's data collection effort is on economic and demographic characteristics, especially with respect to earned and unearned income (welfare as well as asset income), employment, family composition, and geographic location.

For the purpose of this study, a key feature of the PSID is the wealth supplements, particularly those collected in 1994 and 2001. Funded by grants through the National Institute on Aging, the wealth supplements contain comprehensive data on net worth, defined as the sum of liquid assets (checking accounts, savings accounts, CDs, IRAs, bond and stock values), the value of business equity, real estate equity, and vehicle equity, less any outstanding debts. The PSID wealth data compares favorably with other, more targeted, wealth surveys such as the Survey of Consumer Finances (SCF) (Curtin, et al. 1989; Juster, et al. 1999), with the added feature that because low-income households are over-sampled we get a more detailed picture of saving among actual and potential welfare recipients. ${ }^{7}$

Aside from the PSID, which contains all pertinent demographic information, the other data needed are information on state-specific welfare policy variables, including asset limits. ${ }^{8}$ The data for these variables come from Gallagher, et al. (1998), Crouse (1999), TANF Report to Congress (1998; 2002), and various issues of the Committee on Ways and Means Green Book. The program data are readily linked to the PSID data via state identifiers. All income and wealth

\footnotetext{
7 A recent study sponsored by the Social Security Administration and conducted by Mathematica Policy Research Institute (Czajka et al., 2003) concludes that the PSID and the SCF provide high quality wealth estimates. They also conclude that data from the Survey of Income and Program Participation (SIPP) dramatically underestimates household wealth holdings.

${ }^{8}$ As we will discuss in Section 6, we also include controls for other state welfare programs including the level and the change in vehicle asset limits, whether the state imposes time limits for welfare receipt, and the level and the change in the state's maximum AFDC/TANF benefit for a three-person household.
} 
data are converted into 1996 dollars using the corresponding seasonally adjusted June CPI-U. As a result, all data in the paper - aside from that which is presented in the appendices describing the change in welfare limits - are in 1996 dollars.

\section{A. Sample Composition}

As argued by the National Research Council (2001), evaluations of welfare reform should not be restricted simply to the population of current recipients or leavers, but rather to the at risk population at large. This coincides with the model by Hubbard, et al. (1995), whereby the populations touched by means-tested asset programs are all households who are "at risk" of ending up welfare. That said, the socio-economic composition of the current welfare population should provide some guidance in determining those households deemed to be at high-risk of welfare use as opposed to those at moderate or low risk of welfare use.

We begin our sample-selection process by examining the socio-economic status of actual welfare recipients in 1994. Using PSID data, the average head of an AFDC family in 1994 was 34 years old and had just over two children, and 80 percent were single women (the residual being two-parent or child-only cases). Over 80 percent of heads receiving AFDC support in 1994 had only a high school degree or less, and the median labor-market income for these heads was a meager $\$ 162$. Very few of these families were 'banked,' i.e. they did not own a checking or savings account, stocks or bonds, a house, or a business. Nearly 80 percent had no liquid assets, 96 percent had liquid assets below the $\$ 1000$ minimum and 93 percent had less than onehalf of the minimum. As we will emphasize below, these latter figures suggest that the liquid asset limits are not binding for essentially all households currently on AFDC in 1994.

To perform our analysis of whether asset limits are a deterrent to household saving, we need to define a group which has a high probability of welfare receipt. Given the above 
description of 1994 welfare recipients, we focus on female headed households who have children under the age of 18 and who have less than 16 years of school. Between the years 1994 and 2001, $48 \%$ of this demographic group participated in AFDC or TANF at some time. ${ }^{9}$ As a group, female headed households with children are at significant risk of welfare take up. This contrasts starkly with other groups in the population. The probability of welfare take up any time between 1994 and 2001 for households in our two comparison groups - male headed households and female headed households with no children - is essentially zero $(1.9 \%$ and $0.0 \%$, respectively). ${ }^{10}$ Given the near zero probabilities of welfare take up in the short term for households in these comparisons groups, asset limits should have little, if any, effect on their saving decisions. However, if asset limits are an important deterrent to savings, female headed households with children should respond to their removal. One further comment on our choice of at-risk sample is warranted. Only $2 \%$ of high educated female headed households with children (i.e., those with 16 or more years of schooling) participated in AFDC/TANF at any time between 1994 and 2001. Given that there is essentially no probability of these high educated female heads to participate in welfare, we restrict our analysis to households where the head has less than a college degree.

The cross-state variation in asset-limit policies is sufficient to identify the effect of asset limit changes on household saving. However, to net out the possibility of spurious relationships between policy changes and economic behavior it is common in the literature to use comparison groups such as female headed households with no children and male headed households (both single and married). Meyer and Rosenbaum (2001) assumed that single, childless women have

\footnotetext{
${ }^{9}$ Below, we discuss the specific PSID sample used to compute the figures in this section. As with the descriptive statistics in Table 1, all probabilities of taking up welfare reported in this section are weighted using 2001 core PSID weights.

${ }^{10}$ The zero probability of AFDC/TANF take up for women without children is not surprising given that a child is necessary for eligibility into these programs. Our women without children sample required that the women didn't have a child in any years between 1994 and 2001.
} 
similar labor-market trends as single women with children and thus function as a valid comparison group to identify the effects of tax and social policy changes in the 1980s and mid1990s on the labor-market behavior of single women with children. We implicitly follow the strategy used by Meyer and Rosenbaum (2001) and compare the saving response to welfare reform by single women with children to those without children. However, we also recognize that while single female heads without children are not currently eligible for cash welfare, they may be eligible in the future if they have children (and have low-incomes and assets). Hence, single women without kids are potentially at moderate risk of future welfare participation and thus may alter their saving in the presence of asset tests. With this in mind, we use male headed households as an additional comparison group. Given the information above, male headed households (with or without children) have essentially a zero take up rate of AFDC/TANF programs. Such a fact makes them unlikely to respond to the AFDC/TANF policy changes.

Formally, we define our full sample as including all PSID households where the head (i) was between the ages of 18 and 44 in 1994, (ii) had less than 16 years of schooling, (iii) remained in the sample continuously between 1994 and 2001, (iv) did not change their state of residence between 1994 and 2001, (v) did not change marital status between 1994 and 2001, and (vi) did not have missing values for wealth in either 1994 or 2001. Lastly, for female headed households, we imposed that there was consistently no children in the household between 1994 and 2001 (female with no children sample) or that there was consistently a child in the household between 1994 and 2001 (female with children sample). In section 6, we report results where some of these restrictions are relaxed. Before we proceed, however, we will discuss our rationale for these restrictions. 
First, we restrict our analysis to households under the age of 44 in 1994 and with less than 16 years of schooling because these are the households with the most risk of welfare take up. As shown above, the AFDC/TANF take up rate for female heads with children who have more than 16 years of schooling was essentially zero. The remaining restrictions (iii - vi) impose that our sample composition is homogenous between 1994 and 2001. By following the same household heads over time we are able to track 7-year changes in the household's asset position and also avoid potential sample composition bias arising from individuals changing family status in response to the policy changes. Such composition changes may plague program evaluations using groups of households over time such as found in repeated cross-section data (Blundell and MaCurdy 1999). Next, holding state of residence fixed allows us to avert potential welfare-migration problems, which in this case could occur if welfare recipients move to states with more generous treatment of assets. ${ }^{11}$

In total, our sample is comprised of 1,418 households. Of that total, 347 households are headed by a female. Of the 347 female headed households, 281 of them have at least one child under the age of 18 present continuously between 1994 and 2001. Table 1 provides descriptive statistics for our full sample, for a sample of households headed by men and by women without children, and a sample of female headed households with children. The median female headed household with children in 1994 (with education < 16 years of schooling) has zero liquid assets and less than $\$ 400$ of net worth. Liquid assets are defined as the sum of cash, checking and saving account balances, and stock and bond holdings. Net worth is the sum of liquid assets,

\footnotetext{
11 Relaxing this restriction raises the sample size by $8.9 \%$, but only by $4.1 \%$ among female heads with children. We reestimated our models without imposing this restriction and our results were unchanged. Additionally, we found no evidence that welfare migration was important. The cross-state moves by female heads were fairly evenly distributed across high asset states and low assets states. Among the set of movers $63 \%$ went to low-asset changing states and $37 \%$ to high-asset changing states. Thus, there is not much evidence of welfare-induced migration.
} 
business equity, home equity and vehicle equity less any non-collateralized debt. This finding suggests that female headed households, as a group, were saving very little as of 1994.

\section{B. Descriptive Statistics}

Panel A of Table 2 shows the wealth holdings in 1994 and 2001 for our sample of female headed households with children, broken down by whether they live in a state that had small (or zero) liquid asset limit increases between 1994 and 2001 or whether they live in a state that had large liquid asset limit increases between 1994 and 2001. We define states that increased their AFDC/TANF liquid asset limit by $\$ 1,000$ or less as states with low asset limit changes. States that increased their liquid asset limit by more than $\$ 1,000$ are considered to be high asset limit changers.

Focusing on Panel A, two things are of note. First, in 1994, nearly all female headed households with children had liquid assets less than their state's AFDC liquid asset limit (87\% in low asset limit changing and $82 \%$ in high asset limit changing states). In 1994, all but two states applied the federal AFDC liquid asset limit of $\$ 1,000$. If welfare asset limits were a binding deterrent to saving, you would expect to see a large amount of households with savings close to the state mandated asset limit. However, this is not the case. Households who have liquid wealth below the asset limits are always far below the limit. Specifically, for female heads with children in low asset limit changing states, 98\% of those with 1994 liquid wealth below the 1994 asset limit had liquid wealth below $\$ 500(0.85 / 0.87)$ and $85 \%$ had zero liquid assets $(0.74 / 0.87)$. The comparable numbers for female heads with children in high asset limit changing states were $94 \%$ and $80 \%$, respectively. The results of Panel A of Table 2 suggest that the original 1994 
liquid asset limits did not appear to be binding for female heads with children in the sense that female heads with children had liquid wealth far below the asset limits. ${ }^{12}$

The low asset holding of female heads is not an artifact of the PSID data. Similar results are found using data on households with less than a college degree both from National Longitudinal Survey of Youth (NLSY) and the Survey of Income and Program Participation (SIPP). ${ }^{13}$ In the 1997 NLSY, the share of families with zero liquid assets is $48.9 \%$, the share with less than $\$ 500$ in liquid assets is $66.9 \%$, and the share with less than $\$ 1000$ in liquid assets is $74.6 \%{ }^{14}$ In the 1993 SIPP data, $84 \%$ of female headed households with children reported having less than $\$ 1,000$ in liquid assets, $78 \%$ had less than $\$ 500$ in liquid assets, and $58 \%$ had zero liquid assets (author's calculation). The differences between the SIPP and PSID most likely arise from the fact that the liquid asset measure in the SIPP data includes cash held outside the banking system. However, even accounting for cash holdings, female heads with children accumulate hardly any liquid assets. ${ }^{15}$

The second thing of note from panel A of Table 2 is that the change in wealth between 1994 and 2001 for female heads with children in high asset limit changing states does not look different than the change in wealth between 1994 and 2001 for females with children in low asset limit changing states. If the welfare limits were a strong deterrent to wealth accumulation, one would predict a bigger increase in wealth accumulation for households who lived in states that

\footnotetext{
12 Data from selected issues of Quarterly Public Assistance Statistics in the 1980s and early 1990s provide supporting evidence consistent with the hypothesis that liquid asset limits do not bind for welfare recipients. The data indicates that only about 4 percent of new AFDC applicants were denied benefits due to asset-limit violations, while only about 1.5 percent of recipients were denied benefits at recertification.

13 The PSID data also calibrates well with the Survey of Consumer Finances (SCF). For example, $74.2 \%$ of all female heads under the age of 65 in the $1989 \mathrm{SCF}$ (regardless of educational attainment or whether children were present in the households) report having liquid assets less than $\$ 5,000$. See Haveman and Wolff (2001). The comparable number for a similarly defined sample within the 1994 PSID data was $80.8 \%$.

${ }_{15}$ We thank Annamaria Lusardi for providing us with statistics from the NLSY.

15 Given its panel dimension, the PSID data is much more appropriate for our analysis than the SIPP data, despite the SIPP's large sample size. The SIPP panel runs from 1996 through 2000 and does not span the change in welfare asset limits. As discussed above, we have examined the mean wealth holdings in the SIPP for different cross sectional years and they line up well with the PSID for the group of households at risk of welfare participation.
} 
relaxed the liquid asset limits the most. This is just not the case. Liquid assets, at the median, did not change at all between 1994 and 2001 for females with children in either the low or the high asset changing states. Median net worth for female heads with children in high asset limit changing states increased less between 1994 and 2001 than the median net worth increase for female heads with children in low asset limit changing states during the same time period ( $\$ 900$ versus $\$ 100$, respectively; $p$-value of difference $=0.08$ ).

Additionally, if the 1994 welfare asset limit of $\$ 1,000$ was a binding constraint for households, we should see the propensity for households to have liquid assets above $\$ 1,000$ increase dramatically between 1994 and 2001 (as the asset limits were relaxed). However, in both low asset limit changing states and high asset limit changing states, there was essentially no increase in the propensity for female heads with children to have liquid assets above $\$ 1,000$ between 1994 and 2001 (0.06 and 0.08 percentage points, respectively; $p$-value of difference $=$ 0.77). Nor was there an increase in the propensity for them to have liquid assets above $\$ 500$ between 1994 and 2001 (0.08 percentage points in both high and low asset limit changing states; p-value of difference $=0.90$ ). Looking down the last two columns of panel A of Table 2, there is no evidence that households who lived in high asset limit changing states increased any measure of their saving more than households living in low asset limit changing states. If anything, measures of saving actually fell for female heads with children in high asset limit changing states relative to the saving in low asset limit states.

Three additional comments are needed with respect to Table 2. First, a potential problem with our empirical strategy could occur if households shelter assets from both welfare agencies and the $P S I D$. If asset sheltering is prevalent, large changes in welfare asset limits should reduce the incentives to shelter. As a result, we may observe an increase in measured assets in the data 
that represents nothing more than a shift from unmeasured (sheltered) savings to measured saving. This, however, seems rather unlikely for most households. An ethnographic study of low-income mothers by Edin and Lein (1997) suggests that some mothers shelter income from welfare authorities but they state clearly that none of the women own liquid assets of any note. If the results of Edin and Lein are not universal, the fact that some households shelter assets could cause us to overstate the effect of changing asset limits on household saving. Given that we are not finding any evidence of increased saving resulting from the change in welfare policies that occurred in the mid 1990s, the potential of hidden assets will not affect our conclusions.

Additionally, as seen in Panel A of Table 2, female headed households with children that lived in states which increased their welfare asset limits the most had higher initial levels of saving in 1994. Specifically, 56\% of female heads with children living in high asset limit changing states owned a car in 1994 and 28\% owned a home in 1994. The comparable numbers for female heads with children living in states with low asset limit changes were $42 \%$ and $16 \%$. Additionally, 35\% of females with children in high asset limit changing states had positive liquid assets. In contrast, only $26 \%$ of female heads with children in low asset limit changing states had positive liquid asset. This suggests that the ex-ante saving propensities of female heads with children living in high asset limit changing states may have been higher than the saving propensities of their counterparts in low asset limit changing states. If households in high asset limit changing states have higher saving propensities, we may find a spurious correlation between a change in liquid asset limits at the state level and a change in household saving.

Using comparison groups can help us to mitigate the impact of this spurious correlation. The sample of male headed households and female heads with no children (Panel B of Table 2) display similar saving patterns across the two types of asset limit changing states. In 1994, male 
heads and female heads with no children who lived in high asset limit changing states had higher net worth, higher vehicle ownership propensities, higher home ownership propensities, and larger changes in median net worth between 1994 and 2001. If households in high asset limit changing states have high saving propensities, we would expect to find a positive correlation between changing asset limits and the saving of male heads and female heads with no children. However, theoretically, these households should not respond at all to changes in asset limits. It should be noted that even if there was a positive spurious correlation between savings behavior and the change in asset limits, we will be biased towards concluding that the initial asset limits were a deterrent to household saving. As we show below, our conclusion is quite the opposite.

Lastly, Table 2 illustrates that, between 1994 and 2001, there was a general increase in asset holdings for all households in all states. This is not surprising for two reasons. First, we are focusing on stable households over time. As households progress through their lifecycle, the permanent income hypothesis predicts that wealth should increase as households age (up until retirement). This fact alone would cause household wealth to be increasing over time for our sample of households. Additionally, the period between 1994 and 2001 was one marked by strong economic growth. Both corporate equity markets and housing markets earned above normal returns during this time. Furthermore, earned income grew at rapid rates (as unemployment rates and duration fell sharply). Both facts decreased welfare caseloads and increased household wealth accumulation.

In the empirical work that comes next, we will control for many facets of the economic environment in the late 1990s. Our identification will mainly come from comparing the savings behavior of female headed households in high asset changing states with the savings behavior of female headed households with children in low asset changing states. To control for underlying 
trends in those states, we are going to use both male headed households and female headed households with no children as comparison groups. As noted above, these comparison groups have essentially no short term probability of ending up on AFDC/TANF. Hence, the change in welfare policies should be uncorrelated with their saving propensities. Such empirical work will provide multivariable analysis for what was done in Table 2. However, by itself, the results in Table 2 are quite powerful. Table 2 shows that no matter how you cut the data in a univariate sense, increasing AFDC/TANF asset limits had no apparent effect on the propensity to accumulate liquid wealth or net worth for female heads with children. As noted above, these results are not limited to the PSID data. We find similar results when examining cross sections from the SIPP and the NLSY. This should not be too surprising given that, as shown in Table 2, the welfare asset limits in 1994 did not seem to serve as a binding constraint for most households.

\section{Empirical Model}

Based on the previous discussions, we develop a multivariate empirical model to relate welfare policies to asset accumulation. To begin we note that while the theoretical model developed within Hubbard, et al. (1995) does not offer a closed-form solution it can, in principle, be solved for either the choice variable (consumption) or the state variable (wealth) via the lifetime budget constraint. Thus the model admits reduced-form specifications based on either wealth levels or wealth flows (saving). We begin with a levels specification for household $i$ in state $k$ at time $t$ :

$$
A_{i k t}=Z_{i k t} \alpha+\varphi L L_{k t}+P_{k t} \lambda+u_{i k t},
$$

where $A_{i k t}$ is a measure of the stock of assets (either liquid assets or net worth), $Z_{i k t}$ is a vector of demographics that reflect household saving preferences such as income, education, age, race, 
gender, marital status, and initial assets, and $L L_{k t}$ is the state-level liquid-asset limit in time $t$. In section 6, we will control for additional welfare policies that may affect household savings. $P_{k t}$ is a vector of state-specific economic conditions and policies such as state unemployment rates and a proxy for the welfare consumption floor in the maximum AFDC/Food Stamp benefit for a family of three.

We specify the composite error term, $u_{i k t}$, as follows:

$$
u_{i k t}=v_{i}+\delta_{k}+\kappa_{t}+v_{i k}+\theta_{i t}+\omega_{k t}+\varepsilon_{i k t}
$$

where $v_{i}$ reflects time-invariant and person-specific preferences for wealth, $\delta_{k}$ reflects timeinvariant and state-specific preferences for wealth, $\kappa_{t}$ is an aggregate time effect that impacts all households identically in a given period, $v_{i k}$ is a time-invariant and person-state preference effect for wealth, $\theta_{i t}$ is an idiosyncratic person and time effect for wealth, $\omega_{k t}$ is a state and time wealth effect, and $\varepsilon_{i k t}$ is an idiosyncratic person-state-time effect. It is clear that by restricting attention to those households who do not change their state of residence, and then first differencing, we can eliminate all forms of unobserved heterogeneity to accumulate wealth that is time invariant and state- or person-specific, i.e. $\Delta v_{i}=\Delta \delta_{k}=\Delta v_{i k}=0$.

In first difference form, our empirical model is:

$$
S_{i k t}=\Delta Z_{i k t} \alpha+\varphi \Delta L L_{k t}+\Delta P_{k t} \lambda+\Delta \kappa_{t}+\Delta \theta_{i t}+\Delta \omega_{k t}+\Delta \varepsilon_{i k t}
$$

where $S_{i k t}$ is the amount of household saving, i.e. $S_{i k t} \equiv \Delta A_{i k t}=A_{i k t}-A_{i k t-1}$. Because we only have two years of wealth data (1994 and 2001), the aggregate time effect, $\Delta \kappa_{t}$, is subsumed into the constant term.

In addition to eliminating time-invariant heterogeneity, first differencing permits us to model some of the remaining heterogeneity in a transparent fashion. Specifically, we model 
changes in the person and year effect as a linear function of baseline demographics of the household, i.e. $\Delta \theta_{i t}=Z_{i k t} \beta$. This permits demographics to have both a level effect (via $Z_{i k t}$ ) and a growth effect (via $\Delta Z_{i k t}$ ) on assets. Likewise, we model changes in state-time effects as a linear function of the baseline state economic conditions, i.e. $\Delta \omega_{k t}=P_{k t} \eta$, such that the consumption floor has both a level and growth effect on assets. Below, we discuss fully the variables included in our $Z_{i k t}$ and $P_{k t}$ controls.

Replacing these terms into equation (3) yields our baseline estimating equation:

$$
S_{i k t}=\delta+Z_{i k t} \beta+\Delta Z_{i k t} \alpha+\varphi \Delta L L_{k t}+P_{k t} \eta+\Delta P_{k t} \lambda+\Delta \varepsilon_{i k t}
$$

Importantly, as discussed in sections II and III, we permit the coefficients on the change in asset limits to differ across various family structures. Specifically, we include the change in the asset limit as a control and along with the asset limit change interacted with a dummy variable for whether the head was a female who had children (and also include a separate dummy variable for female heads with children to capture level differences).

Based on the previous discussion, the sign of $\varphi$ should be positive for households at high risk of entering welfare. For example, female headed households with children should respond more strongly to the policy changes than either male headed households or female headed households without children. Because saving by members of the comparison group should not respond to the change in welfare policy, the coefficient $\varphi$ should be zero.

Before going to the results section, a comment is needed on how big an effect we should expect the change in asset limits to have on the wealth accumulation of women with children between 1994 and 2001. While savings rates may respond quickly after the implementation of the welfare reform policies, the stock of savings may respond much more slowly. The question we wish to address is: "Given reasonable savings propensities, how much additional asset 
accumulation should we expect when welfare asset limits are increased in 1996?" Female headed households with children earned, on average, $\$ 14,000$ of labor income between 1994 and 2001 (Table 1). If such households had a $10 \%$ savings rate, we would expect them to accumulate an additional $\$ 7,000$ in net worth during the 5 years between 1996 and 2001 ( $\$ 1,400 /$ year). We start our hypothetical in 1996 , given that is the year the asset limits were relaxed for almost all states. If the households only had a 5\% savings rate, we would expect their accumulated savings to increase by $\$ 3,500$ during the five years between 1996 and 2001 . This implies that if their state's asset limit increased by $\$ 1,000$ (the median increase for households in the sample), their savings should increase by the full $\$ 1,000$. Given our sample, $71 \%$ of female headed households live in states where the liquid asset limit increased by less than $\$ 1,500$ and $96 \%$ lived in states where the liquid asset limit increased by less than $\$ 2,000$. In other words, $\varphi$ should be close to 1 for the median female headed households with children even if they only had a savings rate of $3 \%$ per year. ${ }^{16}$

\section{Results}

In the ensuing tables we focus attention on the coefficients associated with the state change in asset limits between 1994 and 2001 and these state asset limit changes interacted with whether the household head was a female with children. However, we do include additional controls for the household head's 1994 age, race, education, and level of liquid assets. We also include controls for the change in household size between 1994 and 2001, the average household labor income between 1994 and 2001, average labor income squared, the change in labor income

\footnotetext{
16 A 3 percent savings rate out of $\$ 14,000$ of annual income results in $\$ 420$ of savings per year. Taken over five years, this implies an additional accumulated amount of savings of \$2,100 between 1996 and 2001.
} 
between 1994 and 2001. Lastly, we include a vector of state specific controls including the state GDP per capita in 1994 and the change in the state unemployment rate between 1994 and $2001 .{ }^{17}$

\section{A. Changes in Liquid Assets}

Before estimating by how much liquid assets increase in response to changes in liquid asset limits, we examine whether the probability of increasing liquid assets differs with respect to changes in welfare asset limits. Panel A of Table 3 has a dependent variable which is equal to 1 if the household increased their liquid assets between 1994 and 2001. Panel B of Table 3 shows the specification from equation (4) where the dependent variable is the actual change in liquid assets between 1994 and 2001. Column I (in both panels A and B) uses a sample where the top and bottom $5 \%$ of the change in liquid asset distribution is truncated. The second column reports the results of equation (4) using the full sample. Given the skewness of the change in liquid asset distribution, we use a robust regression estimator for the Panel B estimates.

Appendix Table A2 shows the results of the complete regression associated with panel B of Table 3 (column I). The main thing to note about Table A2 is that for our PSID sample, liquid assets vary as would be predicted by the permanent income hypothesis. In this specification, household liquid asset accumulation is a convex function of average family income. For households with average earned income above $\$ 12,500$, household saving between 1994 and 2001 is strictly increasing in income. Also, households who had positive income growth between 1994 and 2001, who were higher educated, and who were white saved more between 1994 and 2001. All of these coefficients were statistically significant at the $1 \%$ level. This is consistent with much of the findings in the literature (see Hurst, Luoh and Stafford 1998).

\footnotetext{
${ }^{17}$ In the ensuing tables the standard errors for the linear probability models are corrected for heteroskedasticity and clustering by state of residence. The standard errors are bootstrapped in the robust regression models.
} 
Such results provide evidence that the PSID wealth data varies across households as one would predict based on economic theory.

If AFDC/TANF asset limits were a hindrance to savings for households at risk of welfare participation, we would expect to see a large response in liquid asset accumulation to their removal. This is just not the case. As seen in panel A of Table 3 (column I), female heads with children did not increase their liquid asset holdings to any significant extent between 1994 and 2001 (coefficient $=0.02$; standard error $=0.04)$. The mean probability of increasing liquid assets between 1994 and 2001 for the sample used in Table 3 (column I) was 0.48 .

Moreover, the propensity for female heads with children to accumulate liquid assets was negatively related to the extent to which the state relaxed liquid asset limits (column I of Panel A). The negative decline, however, was not significantly different from zero (point estimate $=$ 0.020 ; standard error $=0.025$ ). The point estimate and the standard error allow us to reject any sizable response on the part of female headed households with children to the change in liquid asset limits. The 95 percent confidence band ranges from -0.07 to 0.03 . Remember from Table 2 that approximately $85 \%$ of female headed households with children had liquid assets less than $\$ 1,000$. If the liquid asset limit was deterring liquid asset accumulation, we would expect that the majority of female heads with children to increase their liquid assets after the assets limits were loosened. As in Table 2, panel A of Table 3 shows that female heads with children were not more likely to increase their savings in response to the relaxation of AFDC/TANF asset limits in the mid-1990s.

Panel B of Table 3 examines the change in actual liquid assets between 1994 and 2001. There is some evidence that male headed households and females without kids increased savings in response to the liquid asset limits. This result, as discussed above, could be the result of a 
spurious correlation between the propensity for an individual to accumulate assets and the extent to which their state increased its liquid asset limit. As seen in Table 2, higher savers (as measured by 1994 characteristics) tend to reside in high asset limit changing states. What is interesting with respect to Table 3, panel B is that female heads with children actually experienced a decline in liquid asset accumulation in response to the increase in their state's asset limit. This response is not statistically different from zero (point estimate $=-0.07$; standard error $=0.10$ ). However, as above, the $95 \%$ confidence band rules out any sizable positive response to the asset limit changes for females with children (confidence band ranges from -0.27 to 0.13 ). The upper bound of the confidence band is well below the predicted increase in savings if households assuming a 3\% savings rate (see expected savings response predicted above). Moreover, they are much smaller than the estimates reported in Powers (1998).

It is possible that the results in Table 3 mask the saving response to the liquid asset change because we include households who were likely not bound by the initial asset limits in 1994. Specifically, if the asset limit in 1994 was binding, households should have accumulated less than $\$ 1,000$ in liquid assets. Column I of Table 4 re-estimates equation (4) on a sample of households who had liquid assets in 1994 less than $\$ 1,000$ (737 households). We run this regression without any truncation. Like for the full sample in Appendix Table A2, we find that higher income, more educated, white households saved much more than other households. However, once we restrict the sample to households that should be bound by the asset limits, none of the welfare policies have any statistical or economic effect. Specifically, the effect of increasing the asset limits on the liquid asset saving for female headed households with children had a $95 \%$ confidence interval of -0.03 to 0.02 (column I of Table 4). Of all the results in the paper, this one proves most challenging for the theory that AFDC liquid asset limits are a 
deterrent to household saving. By focusing on households that should be bound by the asset limit (those with initial liquid asset less than $\$ 1,000$ ) and focusing on those who are most likely to take up AFDC/TANF (female heads with children), we find no response at all to the change in liquid asset limits.

In columns II and III of Table 4, we increase the sample restriction for 1994 liquid assets from $\$ 1,000$ to $\$ 2,500$ (column II) and from $\$ 1,000$ to $\$ 5,000$ (column III). We do so to account for the possibility that the near poor, i.e. those low-income families who maintain a low stock of wealth in the event that a negative income shock would force them onto welfare, may respond to the higher asset limits. The results are nearly identical to what was reported in Table 3 and column I of Table 4. Female heads with children do not respond to the increase in liquid asset limits. Reasonable saving rates predict that $\varphi$ from equation (4) should be close to 1 if the liquid asset limits are binding. Collectively, the results from Tables 3 and 4 suggest that $\varphi$ is close to zero. Even though we have small sample sizes, we can statistically reject that $\varphi$ is greater than 0.05 for female heads with children (using the 95 percent confidence bands from Table 4). In summary, our $95 \%$ confidence band estimates of the impact of relaxing liquid asset limits on the liquid asset accumulation of female heads with children range from -0.13 to 0.05 , with the mean point estimate being -0.03 (Table 4 results). ${ }^{18}$

\section{B. Changes in Asset Ownership}

One of the major rationales for relaxing welfare liquid asset limits was to promote selfsufficiency among the population at risk for welfare take up. In this section, we examine the extent to which female heads with children enter different asset markets in response to changes

\footnotetext{
18 Tables 3 and 4 were also estimated using state fixed effects. The coefficients on the change in asset limits interacted with the dummy for female head with children did not change when state fixed effects were included. In earlier versions of the paper, we directly explored the endogeneity of the state's welfare policy changes with respect to the savings behavior of citizens within its state. We found no evidence that such endogeneity was important. See Hurst and Ziliak (2001).
} 
in state liquid asset limits. Table 5 examines the transition into checking account ownership, vehicle ownership, home ownership, stock ownership or small business ownership between 1994 and 2001. The control variables are exactly the same as those used in Tables 3 and 4. For the results in Table 5, we use the untrimmed sample (column II of Table 3). The only additional restriction we make to the sample is that the households in the sample do not own the given asset in 1994. That is, we want to ask if the relaxation of the welfare asset limits spurred entry into different asset categories. For example, in column I of Table 5, we examine the transition into checking/saving account ownership for households who did not own a checking/savings account in 1994. Similar restrictions are imposed for columns II-V of Table 5.

Overall, as seen in column I to Table 5, female heads with children were more likely to start a checking or savings account than the comparison group of male headed households or female heads with no children (coefficient $=0.07$; standard error $=0.06$ ). However, the propensity to own a checking account is unrelated to the change in the state asset limit. If anything, female heads with children may have been slightly less likely to start a checking account if they lived in a state which had large increases in welfare asset limits (coefficient = 0.02 with a standard error of 0.02 ). The 95 percent confidence bands imply that the propensity to become a checking or savings account owner changes by -0.06 to 0.02 percentage points for every $\$ 1,000$ increase in the states welfare asset limit. This effect is both economically and statistically equal to zero. Similar results hold for entering home ownership (column III), becoming a stock owner (column IV), and starting a business (column V). Female heads with children entered these markets with a lower probability than similar male or female headed households with no children. More importantly, their propensity to enter these markets was unrelated to the relaxation of welfare asset limits. 
One notable exception was entering vehicle ownership (column II of Table 5). Females with kids were 17 percentage points less likely to become a car owner than male headed households or female headed households with no children (standard error $=0.08$ ). However, this negative propensity diminished for females who lived in high asset limit changing states. Formally, every $\$ 1,000$ increase in asset limits increased a female headed household with children's propensity of owning a car by 13 percentage points (standard error $=0.05$ ). This implies that a female head with children who lived in a state where the asset limit remained constant (in real terms) was 17 percentage points less likely to buy a car between 1994 and 2001. A female head with children who lived in a state where the asset limit increased by $\$ 1,000$ (in real terms) was 4 percentage points less likely than the comparison group to buy a car between 1994 and $2001(-0.17+0.13)$. A female head with children who lived in a state where the asset limit increased by $\$ 2,000$ (in real terms) was 9 percentage points more likely to buy a car during that same time period $(-0.17+0.26)$. Of all the results in the paper, we only find a positive effect of relaxing liquid limits on the propensity to purchase a car. In terms of increasing self sufficiency during the late 1990s for female heads with children, even this effect is small for those living in states with large liquid asset limit increases.

\section{Net Worth and the Powers Sample}

In this section, we examine the effects of relaxing liquid asset limits on net worth. Given the results above, there is little reason to believe that net worth will change. We have shown that changes in liquid asset limits did not affect changes in the level of liquid assets for female heads with children nor did they affect the propensity to start a business, open a checking account, purchase stocks, or buy a home for these households. In this sub-section, we re-estimate equation (4) by replacing the change in liquid assets between 1994 and 2001 with the change in net worth 
between 1994 and 2001. For consistency with Powers (1998), we restrict the sample to only female headed households with children. This eliminates our use of the comparison groups of men and female heads without children. Powers, using NLSY data, had a sample of 221 households. Our sample, using the PSID, has 274 households.

The coefficient on the liquid asset limit change for this sample with the dependent variable being the change in net worth between 1994 and 2001 was -0.49 (standard error $=0.42$ ). If we restrict the analysis to households with initial net worth in $1994<\$ 1,000$ or initial net worth in $1994<\$ 5,000$, our estimates were, respectively, 0.01 (standard error $=0.20$ ) and -0.20 (standard error $=0.27) . \quad$ The standard errors on our estimates are quite large (as are those in Powers' net wealth regressions). However, in all our specifications the point estimate was zero or largely negative. Moreover, if we run a simple regression where the dependent variable is a dummy variable indicating whether the change in net worth was positive, we find that the coefficient on a $\$ 1,000$ change in asset limits is 0.01 with a standard error of 0.03 . This implies that while the actual net worth change may be noisily estimated, the probability of increasing net worth increased by essentially zero in response to the relaxation of liquid asset limits.

That we are unsuccessful in replicating Powers' point estimate of 0.25 may be due to a number of reasons. First, Powers uses nominal dollars for her income and wealth calculations, which may lead to a spurious positive finding in her results as the 1979-1983 period was a time of high inflation (e.g. average annual nominal income grew at 11 percent per year for her sample, even though real incomes among female heads fell overall). Second, her sample period spanned a severe recession whereas ours is a period of expansion, and she did not include controls for state business cycles as we do. Third, the quality of her NLSY net worth measure is likely inferior to the one we use in the PSID both because the NLSY does not have vehicle equity and 
it does not have as broad a measure of outstanding debts as in the PSID. Lastly, and perhaps most importantly, there is evidence that a state's choice of welfare asset limit is positively related to the saving behavior of households in those states (Table 2). In our analysis, we take this correlation seriously by using comparison groups and by restricting our focus to only those households who could have been conceivably bound by the initial policies.

\section{Robustness}

\section{A. Examining Other Policy Reforms}

The PRWORA legislation introduced a plethora of additional programmatic changes to cash welfare, some of which were expected to directly affect saving, others of which were expected to affect saving indirectly via changes in labor-market earnings. Included in the latter group are work requirements for benefit receipt and benefit sanctions for failure to follow program rules. To the extent that saving and earnings are positively correlated, these work policies are expected to raise saving insofar as they raise earnings. All of our empirical work above controls directly for levels and changes in household earnings. For completeness we also experimented with including controls to capture state work requirements (not reported). The inclusion of such variables neither directly affected household saving (once controlling for earnings), nor did their inclusion alter any of the parameter estimates discussed above.

Aside from relaxing liquid asset limits and implementing work requirements, PWRORA allowed states to alter other policies regarding their delivery of cash welfare. In particular, many states altered their vehicle asset limits and imposed time limits on the receipt of welfare benefits. We briefly address each of these two policy changes, in turn.

First, prior to PRWORA, almost all states had a binding vehicle asset limit of $\$ 1500$. Currently, 22 states allow unlimited vehicle equity on at least one automobile. For those that 
restrict the amount of vehicle equity, the vehicle equity limits have been significantly expanded. Appendix Table A1 summarizes the changes in vehicle equity limits across states. If the vehicle limit was initially binding, we would predict that relaxing the vehicle limit would stimulate either car ownership directly or it would stimulate liquid asset accumulation (giving a greater incentive to save for a car down payment). We will test for this directly by augmenting equation (4) with two additional variables: 1) a dummy variable indicating whether the state has a binding vehicle equity limit and 2) the change in the vehicle asset limit if the state does not allow unlimited vehicle equity. We predict the coefficient on the first variable would be negative and the coefficient on the second variable would be positive. In other words, the higher the new limit, the bigger the increase in savings.

Additionally, we control directly for whether the state has imposed welfare time limits. Under AFDC recipients remained eligible for benefits so long as they met program eligibility rules. However, PRWORA fundamentally changed the provision of benefits by imposing a lifetime limit on benefit receipt. This provision was a culmination of waivers from federal rules that were implemented in several states in the mid 1990s. Because the limit may be lowered at state discretion, nineteen states have opted to lower the time limits below the sixty-month federal maximum. Four states (California, Maryland, New York, and Rhode Island) have opted to provide a reduced benefit to the family or children after the sixty-month time limit is reached, while Michigan has opted out of terminal time limits altogether and will provide the full benefit out of state funds after the federal limit is reached. States are permitted to exempt up to twenty percent of their caseload from the time limits for any reason. Appendix Table A3 provides a summary of state time limits. To capture the effects of time limits, we include a variable that 
measures (in months) the maximum amount of time a household can receive TANF benefits. All else equal, at risk households living in states with a shorter time limit should save more. ${ }^{19,20}$ In Table 6 we show the results of three specifications on the trimmed sample from Table 3: a linear probability model of whether liquid assets increased between 1994 and 2001; a robust regression model of the dollar change in liquid assets; and a linear probability model of whether vehicle equity increased between 1994 and 2001. In the first model there is some weak evidence $(p$-value $=0.19)$ that controlling for other policies the saving of female heads with children was about 3 percentage points higher per $\$ 1000$ increase in the asset limit relative to the comparison group, but the total effect of 6 percent is small. However, except for the indicator on whether the state has a vehicle limit, none of the other policies are economically or statistically significant in any of the three specifications. In the case of the vehicle limit the results in column 1 of Table 6 indicate that female heads with kids are 34 percent less likely to have a positive change in their liquid asset position relative to the comparison group, but for those residing in states with vehicle limits that probability is lowered by 22 percent. The latter is contrary to expectations, but it disappears once we control for state fixed effects (not tabulated).

\section{B. Program Interactions and Excess Zeros}

Nearly 90 percent of AFDC/TANF recipients also receive assistance from the Food Stamp Program. In the years leading up to welfare reform, the nominal food-stamp liquid asset limit of $\$ 2000$ (for non-elderly families) was double the nominal AFDC asset limit. However, after welfare reform in the mid 1990s, many states increased their asset limit above the food

\footnotetext{
${ }^{19}$ We also control for the level and change in welfare benefits between 1994 and 2001, as summarized in Appendix Table A4.

${ }^{20}$ In an earlier version of this paper we included an indicator variable for the presence of an Individual Development Account (IDA) program. Such a program offers state matching funds for targeted saving by low income households. The saving is earmarked for specific goals like human capital accumulation or the down payment for a home. The coefficient on the IDA dummy was economically small and statistically zero. Because of the limited availability of the IDA program relative to other statewide reforms like asset limits and time limits we drop IDAs from the current paper and leave the evaluation of this potentially important program to future research. None of the results presented in this paper are sensitive to the inclusion of IDA controls.
} 
stamp limit, which remained fixed at $\$ 2000$ (in nominal terms). In the wake of welfare reform, the interaction effect between the resource limits in TANF and food stamps is complicated. TANF recipients continue to remain categorically eligible for food stamps even in states with asset limits above the federally set food stamp limit. For such households, it is the TANF asset limits that are binding. However, families strictly on food stamps in the higher TANF-limit states are held to the food stamp resource rules. Likewise, those families who enter TANF after first participating on food stamps are likely to view the food stamp limit as the relevant binding constraint.

To permit the possibility of program interactions we redefine our asset limit variable in a given year to equal the minimum of the AFDC/TANF or food stamp asset limit. This implies that identification of the asset limit change is based primarily on those states that increase their limit above the food stamp limit. In previous versions of this paper, we explore this interaction more fully (see Hurst and Ziliak 2001). In summary, the results are unchanged when allowing for policy interactions. There is no evidence that female heads with children responded to changes the welfare asset limits.

To this point we have treated households with no assets as indistinguishable from those with positive or negative values. It is conceivable that these families are different, and that the differences are not randomly distributed; that is, some households may face a 'hurdle' to enter financial markets. For example, some families may face borrowing constraints that inhibit their ability to assume debt (note in Table 2 that only 30 percent of female heads with children have debt compared to 50 percent among the comparison groups), others may have extremely high time discount rates, while still others may have time inconsistent preferences (Laibson 1997). If there are unobservable factors that are common to the decision of whether to save (dissave) and 
the amount saved (dissaved) then least squares estimates will not be consistent. Additionally, while it is possible that there is no behavioral distinction between those with zero saving and those with positive or negative levels of saving, the fact that nearly half of our high-risk sample are at zero implies that there are important nonlinearities in the data that linear least squares will insufficiently capture. In Hurst and Ziliak (2001) we consider several variants of a two-step hurdle model where in the first step we estimate the probability of non-zero saving and in the second step we estimate the effect of asset limit changes on saving conditional on a sample selection rule. Again, our central conclusion that the saving of families at greatest risk of welfare use does not respond to changes in welfare asset limits remains unchanged.

\section{Conclusion}

Are the 'poor' on the road to self-sufficiency after welfare reform? The evidence presented here suggests that to date little progress is being made with respect to improved financial balance sheets. In general, the new saving incentives available to current and prospective welfare recipients have had at best a negligible economic impact on saving, with the possible exception of fostering the acquisition of a vehicle. Perhaps it is still premature to make definitive claims on saving given the infancy of all the new programs. But, as noted throughout the paper, even with modest saving rates, the relaxation of welfare limits should have increased savings by a sizeable amount between 1996 and 2001. At the same token, nearly 85 percent of high welfare-risk households (i.e., female household heads with children) held liquid wealth below one half of the pre- welfare-reform limit. This suggests that the limits are rarely binding for most households and thus, it is not too surprising that saving only responds minimally to the majority of the large changes in saving incentives offered through the welfare system. 
The model in Hubbard, et al. (1995) clearly recognized that not only may asset limits deter saving but also the fact that income transfers provide a consumption floor and thus reduce the need for precautionary saving. Indeed, Ziliak (2003) showed both that means-tested transfers (i.e. AFDC/TANF, food stamps, and SSI) reduce liquid asset accumulation among the poor and that the poor show few signs of precautionary saving. In contradistinction, these programs did not affect asset accumulation among the near poor and non poor, yet the latter groups demonstrated precautionary saving behavior. Likewise, Neumark and Powers (1998) showed that the consumption floor provided by SSI reduces saving among the poor near retirement, while Engen and Gruber (2001) find that the floor provided by Unemployment Insurance reduces saving. While the latter three studies did not separately identify the impact of asset limits from the consumption floor (note that there are no asset limits imposed on UI receipt), their results, coupled with the lack of asset-limit effects found in this study, point to the conclusion that if welfare programs do affect household savings it may be via access to the consumption floor and not asset limits per se.

What is self evident from this study is that any theory put forth to explain the asset accumulation of low-income households needs to reconcile the large percentage of households who persistently hold zero liquid assets. However, these theories need not rely on nonoptimizing households. Variants of the life cycle model where households have high intertemporal discount rates or have time inconsistent preferences have been shown through calibration and simulation to match the large fraction of households with zero liquid assets in the data (see Angeletos et al., 2001). Regardless, the road to self-sufficiency for the poor is long indeed. 


\section{REFERENCES}

Angeletos, M., D. Laibson, A. Repetto, and J. Tobacmam, and S. Weinberg. 2001. "The Hyperbolic Buffer Stock Model: Calibration, Simulation and Empirical Evaluation." Journal of Economic Perspectives, 15(3), pp. 47-68.

Blundell, R. and T. MaCurdy. 1999. "Labour Supply: A Review of Alternative Approaches." In Handbook of Labor Economics, Volume 3A, A. Ashenfelter and D. Card (eds.), Amsterdam: North Holland, 1559-1695.

Browning, M. and Lusardi, A. 1996. "Household Saving: Micro Theories and Macro Facts." Journal of Economic Literature, 34(4), pp. 1797-1855.

Carney, S. and Gale, W. 2001. "Asset Accumulation Among Low-Income Households." In Assets for the Poor, T. Shapiro and E. Wolff (eds.), New York: Russell Sage Foundation, 165-205.

Charles, K. and Hurst, E. 2002. "The Transition to Home Ownership and the Black-White Wealth Gap." Review of Economics and Statistics.

Crouse, G. 1999. "State Implementation of Major Changes to Welfare Policies, 1992-1998." Technical Document, URL: http://aspe.hhs.gov/hsp/Waiver-Policies99/policy_CEA.htm.

Curtin, R.; Juster, F. T. and Morgan, J. 1989. "Survey Estimates of Wealth: An Assessment of Quality." in R. Lipsey and H. Tice, eds., The Measurement of Saving, Investment, and Wealth, Chicago: University of Chicago Press, pp. 473-548.

Czajka, John, Jonathan Jacobson, and Scott Cody. 2003. "Survey Estimates of Wealth: A Comparative Analysis and Review of the Survey of Income and Program Participation". Mathematica Policy Research Report (PR03-45), Washington D.C.

Danziger, S.; Haveman, R. and Plotnick, R. 1981. "How Income Transfer Programs Affect Work, Savings, and the Income Distribution: A Critical Review." Journal of Economic Literature, 19(3), pp. 975-1028.

Edin, K. and Lein, L. 1997. Making Ends Meet: How Single Mothers Survive Welfare and LowWage Work. New York: Russell Sage Foundation.

Gallagher, L.; Gallagher, M.; Perese, K; Schreiber, S. and Watson, K. 1998. "One Year After Federal Welfare Reform: A Description of State Temporary Assistance for Needy Families (TANF) Decisions as of October 1997," Washington, D.C.: The Urban Institute.

Gruber, J. and Yelowitz, A. 1999. "Public Health Insurance and Private Saving." Journal of Political Economy, 107(6), pp. 1249-1274. 
Haveman, R. and Wolff, E.N. 2001. "Who Are the Asset Poor?: Levels, Trends, and Composition, 1983-1998." Institute for Research on Poverty Discussion Paper 1227-01.

Hubbard, R.G.; Skinner, J. and Zeldes, S. 1995. "Precautionary Saving and Social Insurance." Journal of Political Economy, 103(2), 360-399.

Hurst, E.; Luoh, M.C. and Stafford, F. 1998. "Wealth Dynamics of American Families, 19841994.” Brookings Papers on Economic Activity, 1998(1), pp. 267-329.

Hurst, E. and Ziliak, J. 2001. "Welfare Reform and Household Saving." Institute for Research on Poverty Discussion Paper 1234-01, University of Wisconsin.

Juster, T.; Smith, J. and Stafford, F. 1999. "The Measurement and Structure of Household Wealth." Labour Economics (forthcoming).

Laibson, D. 1997. "Golden Eggs and Hyperbolic Discounting," Quarterly Journal of Economics, 112(2), 443-77.

Lawrance, E. 1991. "Poverty and the Rate of Time Preference." Journal of Political Economy, 99(1), 54-77.

Meyer, B. and Rosenbaum, D. 2001. "Welfare, the Earned Income Tax Credit, and the Labor Supply of Single Mothers.” Quarterly Journal of Economics, 116(3), 1063-1114.

National Research Council. 2001. Evaluating Welfare Reform in an Era of Transition. Panel on Data and Methods for Measuring the Effects of Changes in Social Welfare Programs, Robert A. Moffitt and Michele Ver Ploeg (eds.), Washington, D.C.: National Academy Press.

Neumark, D. and Powers, E. 1998. "The Effect of Means-Tested Income Support for the Elderly on Pre-Retirement Saving: Evidence from the SSI Program in the U.S." Journal of Public Economics, 68(2), 181-205.

Powers, E. 1998. "Does Means-Testing Welfare Discourage Saving? Evidence from a Change in AFDC Policy in the United States." Journal of Public Economics, 68(1), pp. 33-53.

Samwick, A. 1997. "Discount Rate Heterogeneity and Social Security Reform." NBER Working Paper \#6219.

Sherraden, M. 1991. Assets and the Poor: A New American Welfare Policy. Armonk, NY: M.E. Sharpe.

U.S. Department of Health and Human Services. 1998. Temporary Assistance to Needy Families (TANF) Program: Annual Report to Congress. Administration for Children and Families. http://www.acf.dhhs.gov/news/welfare/congress/index.htm . 
Ziliak, J. 2003. "Income Transfers and Assets of the Poor." Review of Economics and Statistics, 85(1), pp. 63-76. 
Table 1: Descriptive Statistics for the Full Sample and Separately by Treatment and Comparison Groups

\begin{tabular}{|c|c|c|c|}
\hline & $\begin{array}{c}\text { Full } \\
\text { Sample }\end{array}$ & $\begin{array}{l}\text { Male Heads and } \\
\text { Female Heads } \\
\text { Without Children }\end{array}$ & $\begin{array}{l}\text { Female Heads } \\
\text { with Children }\end{array}$ \\
\hline Age & 33.7 & 33.9 & 31.6 \\
\hline$\%$ with Education $<12$ & 0.15 & 0.11 & 0.28 \\
\hline$\%$ with Education $=12$ & 0.54 & 0.56 & 0.37 \\
\hline$\%$ with Education $>12$ & 0.33 & 0.33 & 0.36 \\
\hline$\%$ where Household Head is Black & 0.20 & 0.14 & 0.60 \\
\hline$\%$ that have children under 17 & 0.62 & 0.57 & 1.0 \\
\hline Number of children under 17 & 1.2 & 1.1 & 2.0 \\
\hline$\%$ on AFDC & 0.06 & 0.02 & 0.39 \\
\hline \% Ever on AFDC, 1994-2001 & 0.07 & 0.02 & 0.48 \\
\hline Mean Household Total Income & 41,100 & 44,800 & 14,600 \\
\hline Median Household Total Income & 33,300 & 39,200 & 10,400 \\
\hline Mean Liquid Assets & 12,800 & 14,300 & 2,100 \\
\hline Median Liquid Assets & 700 & 1,500 & 0 \\
\hline Mean Net Worth & 67,200 & 74,200 & 16,900 \\
\hline Median Net Worth & 16,400 & 25,400 & 400 \\
\hline Mean Change in Liquid Assets (94-01) & 4,400 & 4,800 & 1,900 \\
\hline Median Change in Liquid Assets (94-01) & 0 & 0 & 0 \\
\hline Mean Change in Net Worth (94-01) & 32,000 & 35,200 & 2,500 \\
\hline Median Change in Net Worth (94-01) & 4,700 & 9,500 & 0 \\
\hline$\%$ in states with high asset limit changes & 0.35 & 0.36 & 0.34 \\
\hline Number of observations & 1,418 & 1,137 & 281 \\
\hline
\end{tabular}

Notes: Data are from the 1994 - 2001 Panel Study of Income Dynamics. All variables are for survey year 1994 unless otherwise indicated. Change in asset holdings are measured between 1994 and 2001 . All dollar amounts are in 1996 dollars. Sample is restricted to all stable households where the head and marital status of the head remained constant between 1994 and 2001 and whose head was aged between 18 and 44 years. Sample is further restricted to households who did not change their state of residence between 1994 and 2001. Lastly, the sample is restricted to include only households with education less than 16 years of schooling. All statistics in this table are weighted using 1997 core PSID weights. Liquid assets are measured as including cash, checking account balances, savings account balances, and stock and bond holdings. See text for full details. Our female headed household with children sample imposes that the female head consistently had a child under the age of 17 in her households for all years between 1994 and 2001. Likewise, female heads without children were required to not have had a child under 17 in her household at any time between 1994 and 2001. 
Table 2: Comparison of Asset Changes by Households Who Lived in States with Low and High Asset Limit Changes

\begin{tabular}{|c|c|c|c|c|c|c|c|c|c|c|}
\hline & \multicolumn{10}{|c|}{ Panel A: Female Headed Households with Children Sample (281 observations) } \\
\hline & 1994 & 2001 & Diff & p-value & 1994 & 2001 & Diff & p-value & Diff-Diff & p-value \\
\hline Liquid Assets (median) & 0 & 0 & 0 & 1.00 & 0 & 0 & 0 & 1.00 & 0 & 1.00 \\
\hline Net Worth (median) & 0 & 900 & 900 & $<0.01$ & 1,900 & 2,000 & 100 & 0.89 & -800 & 0.08 \\
\hline$\%$ with Liquid Assets $>\$ 1,000$ & 0.13 & 0.19 & 0.06 & 0.14 & 0.18 & 0.26 & 0.08 & 0.07 & 0.02 & 0.77 \\
\hline$\%$ with Liquid Assets $>\$ 500$ & 0.15 & 0.23 & 0.08 & 0.07 & 0.23 & 0.31 & 0.08 & 0.17 & 0.00 & 0.90 \\
\hline$\%$ with Liquid Assets $>\$ 0$ & 0.26 & 0.41 & 0.15 & $<0.01$ & 0.35 & 0.45 & 0.10 & 0.13 & -0.05 & 0.41 \\
\hline$\%$ Owning a Car & 0.42 & 0.60 & 0.18 & $<0.01$ & 0.56 & 0.67 & 0.11 & 0.10 & -0.07 & 0.33 \\
\hline \multirow{3}{*}{$\%$ Owning a Home } & 0.16 & 0.26 & 0.10 & 0.03 & 0.28 & 0.32 & 0.04 & 0.56 & -0.06 & 0.27 \\
\hline & \multicolumn{4}{|c|}{ States with Low Asset Limit Changes } & \multicolumn{4}{|c|}{ States with High Asset Limit Changes } & & \\
\hline & 1994 & 2001 & Diff & p-value & 1994 & 2001 & Diff & p-value & Diff-Diff & p-value \\
\hline Liquid Assets (median) & 1,600 & 1,800 & 200 & 0.72 & 1,300 & 1,800 & 500 & 0.14 & 300 & 0.57 \\
\hline Net Worth (median) & 22,900 & 38,800 & 15,900 & $<0.01$ & 27,100 & 44,000 & 16,900 & $<0.01$ & 1,000 & 0.92 \\
\hline$\%$ with Liquid Assets $>\$ 1,000$ & 0.57 & 0.57 & 0.00 & 0.87 & 0.55 & 0.57 & 0.02 & 0.54 & 0.02 & 0.42 \\
\hline$\%$ with Liquid Assets $>\$ 500$ & 0.66 & 0.64 & -0.02 & 0.54 & 0.62 & 0.63 & 0.01 & 0.73 & 0.03 & 0.37 \\
\hline$\%$ with Liquid Assets $>\$ 0$ & 0.74 & 0.78 & 0.04 & 0.06 & 0.73 & 0.76 & 0.03 & 0.22 & -0.01 & 0.81 \\
\hline \% Owning a Car & 0.86 & 0.88 & 0.02 & 0.26 & 0.90 & 0.91 & 0.01 & 0.65 & -0.01 & 0.61 \\
\hline \% Owning a Home & 0.57 & 0.68 & 0.11 & $<0.01$ & 0.67 & 0.74 & 0.07 & 0.01 & -0.04 & 0.15 \\
\hline
\end{tabular}


Table 3: Response of Liquid Assets Accumulation to Relaxation of State Asset Limits

\begin{tabular}{|c|c|c|}
\hline \multicolumn{3}{|c|}{$\begin{array}{c}\text { Panel A: Dependent Variables is a Dummy Variable }=1 \text { if Change in Liquid Assets } \\
\text { between } 1994 \text { and } 2001 \text { is Positive (OLS Regressions) }\end{array}$} \\
\hline Coefficient & $\mathrm{I}$ & II \\
\hline Change in State Asset Limit x 1000 & $\begin{array}{c}0.025 \\
(0.008)\end{array}$ & $\begin{array}{l}0.025 \\
(0.011)\end{array}$ \\
\hline Female with Kids * Change in State Asset Limit x 1000 & $\begin{array}{l}-0.020 \\
(0.025)\end{array}$ & $\begin{array}{l}-0.016 \\
(0.026)\end{array}$ \\
\hline Female with Kids Dummy & $\begin{array}{c}0.020 \\
(0.040)\end{array}$ & $\begin{array}{l}-0.026 \\
(0.035)\end{array}$ \\
\hline Truncated Change in Liquid Asset Sample & Yes & No \\
\hline \multicolumn{3}{|c|}{$\begin{array}{l}\text { Panel B: Dependent Variables is Actual Change in Liquid Assets between } 1994 \text { and } 2001 \\
\text { (Robust Regressions) }\end{array}$} \\
\hline Coefficient & $\mathrm{I}$ & II \\
\hline Change in State Asset Limit & $\begin{array}{c}0.082 \\
(0.044)\end{array}$ & $\begin{array}{c}0.037 \\
(0.054)\end{array}$ \\
\hline Female with Kids * Change in State Asset Limit & $\begin{array}{c}-0.073 \\
(0.100)\end{array}$ & $\begin{array}{c}0.009 \\
(0.129)\end{array}$ \\
\hline Female with Kids Dummy & $\begin{array}{c}125 \\
(137)\end{array}$ & $\begin{array}{c}134 \\
(172)\end{array}$ \\
\hline Truncated Change in Liquid Asset Sample & Yes & No \\
\hline
\end{tabular}

Notes: Data is from the Panel Study of Income Dynamics. See footnote to Table 1 for full sample description. Column I imposes the additional restriction that households in the top and bottom 5\% of the change in liquid assets distribution (between 1994 and 2001) are truncated (1,238 households). Column II reports the results from the original (un-truncated) sample (1,418 households). All regressions include demographic, income and state economic controls. See Appendix A2 for the full results to the regressions reported. The standard errors for Panel A are robust to heteroskedasticity and within-state autocorrelation, while those in Panel B are bootstrapped standard errors. 
Table 4: Response of Liquid Assets Accumulation to Relaxation of State Asset Limits, Restricting Sample to Those Potentially Bound By Initial Asset Limit

\begin{tabular}{lccc}
\hline & I & II & III \\
\cline { 2 - 4 } Coefficient & $\begin{array}{c}1994 \\
\text { Liquid Assets } \\
\leq \$ 1,000\end{array}$ & $\begin{array}{c}1994 \\
\text { Liquid Assets } \\
\leq \$ 2,500\end{array}$ & $\begin{array}{c}\text { Liquid Assets } \\
\leq \$ 5,000\end{array}$ \\
\hline Change in State Asset Limit & 0.010 & 0.048 & 0.079 \\
Female with Kids * Change in State Asset Limit & $(0.004)$ & $(0.020)$ & $(0.026)$ \\
Female with Kids Dummy & -0.005 & -0.061 & -0.080 \\
Truncated Change in Liquid Asset Sample & $(0.008)$ & $(0.038)$ & $(0.054)$ \\
Sample Size & 7 & 95 & 138 \\
& $(11)$ & $(52)$ & No \\
& & & No \\
\end{tabular}

Notes: Data is from the Panel Study of Income Dynamics. See footnote to Table 1 for full sample description. Base sample is the same as the untrimmed sample from Table 3 with the following additional restrictions: Column I imposes that households have initial assets less than $\$ 1,000$ in 1994 , Column II imposes that households have initial assets less than $\$ 2,500$ in 1994 , and Column III imposes that households have initial assets less than $\$ 5,000$ in 1994 . Dependent variable is the change in liquid assets between 1994 and 2001. All regressions include the same demographic, income and state economic controls as included in the regressions reported in Table 3. Bootstrapped standard errors from the robust regressions are reported in parentheses. 
Table 5: Change in Asset Ownership between 1994 and 2001 as a Function of State Asset Limit Changes

\begin{tabular}{|c|c|c|c|c|c|}
\hline & \multicolumn{5}{|c|}{ Dependent Variable (Dummy Variable $=1$ if Own Asset) } \\
\hline & $\begin{array}{c}\text { I. } \\
\text { Own } \\
\text { Checking }\end{array}$ & $\begin{array}{c}\text { II. } \\
\text { Own } \\
\text { Vehicle }\end{array}$ & $\begin{array}{c}\text { III. } \\
\text { Own } \\
\text { Housing }\end{array}$ & $\begin{array}{c}\text { IV. } \\
\text { Own } \\
\text { Stocks } \\
\end{array}$ & $\begin{array}{c}\mathrm{V} . \\
\text { Own } \\
\text { Business }\end{array}$ \\
\hline Change in State Asset Limit *1,000 & $\begin{array}{c}0.026 \\
(0.037)\end{array}$ & $\begin{array}{l}-0.058 \\
(0.037)\end{array}$ & $\begin{array}{c}0.020 \\
(0.023)\end{array}$ & $\begin{array}{l}-0.018 \\
(0.008)\end{array}$ & $\begin{array}{c}0.014 \\
(0.011)\end{array}$ \\
\hline Female with Kids * Change in State Asset Limit * 1,000 & $\begin{array}{l}-0.017 \\
(0.023)\end{array}$ & $\begin{array}{c}0.128 \\
(0.051)\end{array}$ & $\begin{array}{c}-0.014 \\
(0.031)\end{array}$ & $\begin{array}{c}0.010 \\
(0.012)\end{array}$ & $\begin{array}{l}-0.005 \\
(0.013)\end{array}$ \\
\hline Female with Kids Dummy & $\begin{array}{c}0.071 \\
(0.055)\end{array}$ & $\begin{array}{l}-0.168 \\
(0.081)\end{array}$ & $\begin{array}{c}-0.049 \\
(0.043)\end{array}$ & $\begin{array}{l}-0.020 \\
(0.022)\end{array}$ & $\begin{array}{c}-0.049 \\
(0.0019)\end{array}$ \\
\hline Mean of Dependent Variable & 0.410 & 0.505 & 0.299 & 0.074 & 0.067 \\
\hline Sample Size & 525 & 288 & 667 & 1,143 & 1,297 \\
\hline
\end{tabular}

Notes: Data is from the Panel Study of Income Dynamics. See footnote to Table 1 for full sample description. Base sample is the same as the untrimmed sample from Table 3 . However, column I restricts to households who did not own a checking or savings account in 1994, column II restricts the sample to households who did not own a vehicle in 1994 , column III restricts the sample to households no owning a home in 1994, column IV restricts the sample to households not owning stocks in 1994, and column V restricts the sample to households not owning a business in 1994. Dependent variable is a dummy variable equal to 1 if the households owned the portfolio component in 2001 . All regressions include the same demographic, income and state economic controls as included in the regressions reported in Table 3 . The standard errors (in parentheses) are robust to heteroskedasticity and within-state autocorrelation. 
Tables 6: Response of Saving to Multiple Welfare Policy Changes

\begin{tabular}{|c|c|c|c|}
\hline \multirow[b]{2}{*}{ Variables } & \multicolumn{3}{|c|}{ Dependent Variable } \\
\hline & $\begin{array}{c}\text { Dummy: } \\
\text { Positive Change } \\
\text { in Liquid Assets } \\
\text { (1994-2001) }\end{array}$ & $\begin{array}{c}\text { Change in } \\
\text { Liquid Assets } \\
\text { (1994-2001) }\end{array}$ & $\begin{array}{c}\text { Dummy: } \\
\text { Positive } \\
\text { Change in } \\
\text { Vehicle Equity } \\
(1994-2001)\end{array}$ \\
\hline \multicolumn{4}{|l|}{ Policy Variables } \\
\hline Change in Asset Limit & $\begin{array}{c}3.95 \text { E-5 } \\
(1.22 \text { E-5) }\end{array}$ & $\begin{array}{c}0.06 \\
(0.05)\end{array}$ & $\begin{array}{c}4.33 \text { E-6 } \\
(1.76 \text { E-5) }\end{array}$ \\
\hline Have a Vehicle Limit & $\begin{array}{c}0.05 \\
(0.04)\end{array}$ & $\begin{array}{c}-66 \\
(141)\end{array}$ & $\begin{array}{c}0.03 \\
(0.04)\end{array}$ \\
\hline Change in Vehicle Limit & $\begin{array}{c}-5.94 \mathrm{E}-6 \\
(7.80 \mathrm{E}-6)\end{array}$ & $\begin{array}{l}-0.01 \\
(0.03)\end{array}$ & $\begin{array}{l}-1.28 \mathrm{E}-5 \\
(1.11 \mathrm{E}-5)\end{array}$ \\
\hline Have a Time Limit & $\begin{array}{l}-0.007 \\
(0.03)\end{array}$ & $\begin{array}{l}-148 \\
(92)\end{array}$ & $\begin{array}{r}-0.002 \\
(0.04)\end{array}$ \\
\hline \multicolumn{4}{|l|}{ Policy Variable * Females $w /$ Children } \\
\hline Change in Asset Limit & $\begin{array}{c}3.27 \text { E-5 } \\
(2.47 \text { E-5) }\end{array}$ & $\begin{array}{l}-0.05 \\
(0.12)\end{array}$ & $\begin{array}{c}4.84 \text { E-5 } \\
(4.21 \text { E-5) }\end{array}$ \\
\hline Have a Vehicle Limit & $\begin{array}{c}0.22 \\
(0.07)\end{array}$ & $\begin{array}{c}57 \\
(301)\end{array}$ & $\begin{array}{c}0.12 \\
(0.11)\end{array}$ \\
\hline Change in Vehicle Limit & $\begin{array}{l}-1.73 \text { E-5 } \\
(1.75 \text { E-5) }\end{array}$ & $\begin{array}{c}0.04 \\
(0.07)\end{array}$ & $\begin{array}{l}-0.03 \\
(0.08)\end{array}$ \\
\hline Have a Time Limit & $\begin{array}{c}0.01 \\
(0.06)\end{array}$ & $\begin{array}{c}59 \\
(206)\end{array}$ & $\begin{array}{c}-2.48 \text { E-6 } \\
(1.86 \text { E-5) }\end{array}$ \\
\hline Dummy: Female Head with Children & $\begin{array}{l}-0.34 \\
(0.32)\end{array}$ & $\begin{array}{c}-433 \\
(1043)\end{array}$ & $\begin{array}{c}0.40 \\
(0.52)\end{array}$ \\
\hline Sample Size & 1,238 & 1,238 & 1,238 \\
\hline
\end{tabular}

Notes: Data is from the Panel Study of Income Dynamics. See footnote to Table 1 for full sample description. The sample is the same as the trimmed sample from Table 3. Dependent variable in column 1 is a dummy variable equal to 1 if the households had a positive change in liquid assets between 1994 and 2001; in column 2 it is the dollar change in liquid assets; in column 3 it is a dummy variable if the family owned a vehicle in 2001 change in vehicle equity was positive. All regressions include the same demographic, income and state economic controls as included in the regressions reported in Table 3 . The standard errors in columns 1 and 3 are robust to heteroskedasticity and within-state autocorrelation, while those in column 2 are bootstrapped. 
Appendix Table A1: Changes in State Asset and Vehicle Equity Limits as of Fiscal Year 2001

\begin{tabular}{|c|c|c|c|c|}
\hline State & Change in Asset Limit & Amount of Change (\$) & $\begin{array}{c}\text { Change in Vehicle } \\
\text { Limit } \\
\end{array}$ & Amount of Change (\$) \\
\hline Alabama & $\mathrm{x}$ & 1000 & $\mathrm{x}$ & one vehicle \\
\hline Alaska & & & $\mathrm{x}$ & all vehicles \\
\hline Arizona & $\mathrm{x}$ & 1000 & $\mathrm{x}$ & one vehicle \\
\hline Arkansas & $\mathrm{x}$ & 2000 & $\mathrm{x}$ & one vehicle \\
\hline California & $\mathrm{x}$ & 1000 & $\mathrm{x}$ & 3150 \\
\hline Colorado & $\mathrm{x}$ & 1000 & $\mathrm{x}$ & one vehicle \\
\hline Connecticut & $\mathrm{x}$ & 2000 & $\mathrm{x}$ & 8000 \\
\hline Delaware & & & $\mathrm{x}$ & 3150 \\
\hline District of Columbia & $\mathrm{x}$ & 1000 & & \\
\hline Florida & $\mathrm{x}$ & 1000 & $\mathrm{x}$ & 7000 \\
\hline Georgia & & & $\mathrm{x}$ & 3150 \\
\hline Hawaii & $\mathrm{x}$ & 4000 & $\mathrm{x}$ & one vehicle \\
\hline Idaho & $\mathrm{x}$ & 1000 & $\mathrm{x}$ & 3150 \\
\hline Illinois & $\mathrm{x}$ & 2000 & $\mathrm{x}$ & one vehicle \\
\hline Indiana & $\mathrm{x}$ & 500 & $\mathrm{x}$ & 3500 \\
\hline Iowa & $\mathrm{x}$ & 4000 & $\mathrm{x}$ & 2459 \\
\hline Kansas & $\mathrm{x}$ & 1000 & $\mathrm{x}$ & one vehicle \\
\hline Kentucky & $\mathrm{x}$ & 1000 & $\mathrm{x}$ & one vehicle \\
\hline Louisiana & $\mathrm{x}$ & 1000 & $\mathrm{x}$ & 8500 \\
\hline Maine & $\mathrm{x}$ & 1000 & $\mathrm{x}$ & one vehicle \\
\hline Maryland & $\mathrm{x}$ & 1000 & $\mathrm{x}$ & one vehicle \\
\hline Massachusetts & $\mathrm{x}$ & 1500 & $\mathrm{x}$ & 3500 \\
\hline Michigan & $\mathrm{x}$ & 2000 & $\mathrm{x}$ & one vehicle \\
\hline Minnesota & $\mathrm{x}$ & 4000 & $\mathrm{x}$ & 6000 \\
\hline Mississippi & $\mathrm{x}$ & 1000 & & \\
\hline Missouri & $\mathrm{x}$ & 4000 & $\mathrm{x}$ & one vehicle \\
\hline Montana & $\mathrm{x}$ & 2000 & $\mathrm{x}$ & one vehicle \\
\hline Nebraska & $\mathrm{x}$ & 4000 & $\mathrm{x}$ & one vehicle \\
\hline Nevada & $\mathrm{x}$ & 1000 & $\mathrm{x}$ & one vehicle \\
\hline New Hampshire & & & $\mathrm{x}$ & one vehicle \\
\hline New Jersey & $\mathrm{x}$ & 1000 & $\mathrm{x}$ & 8000 \\
\hline New Mexico & $\mathrm{x}$ & 2500 & $\mathrm{x}$ & one vehicle \\
\hline New York & $\mathrm{x}$ & 1000 & $\mathrm{x}$ & 3150 \\
\hline North Carolina & $\mathrm{x}$ & 2000 & $\mathrm{x}$ & 3500 \\
\hline North Dakota & $\mathrm{x}$ & 7000 & $\mathrm{x}$ & one vehicle \\
\hline Ohio $^{\mathrm{a}}$ & $\mathrm{x}$ & no limit & $\mathrm{x}$ & one vehicle \\
\hline Oklahoma & & & $\mathrm{x}$ & 3500 \\
\hline Oregon & $\mathrm{x}$ & 1500 & $\mathrm{x}$ & 8500 \\
\hline Pennsylvania & & & $\mathrm{x}$ & one vehicle \\
\hline Rhode Island & & & $\mathrm{x}$ & 3150 \\
\hline South Carolina & $\mathrm{x}$ & 1500 & $\mathrm{x}$ & 8500 \\
\hline South Dakota & $\mathrm{x}$ & 1000 & $\mathrm{x}$ & 3150 \\
\hline Tennessee & $\mathrm{x}$ & 1000 & $\mathrm{x}$ & 3100 \\
\hline Texas & $\mathrm{x}$ & 1000 & $\mathrm{x}$ & 3150 \\
\hline Utah & $\mathrm{x}$ & 1000 & $\mathrm{x}$ & 6500 \\
\hline Vermont & & & $\mathrm{x}$ & one vehicle \\
\hline Virginia & & & $\mathrm{x}$ & 6000 \\
\hline Washington & $\mathrm{x}$ & 3000 & $\mathrm{x}$ & 3500 \\
\hline West Virginia & $\mathrm{x}$ & 1000 & $\mathrm{x}$ & 3000 \\
\hline Wisconsin & $\mathrm{x}$ & 1500 & $\mathrm{x}$ & 8500 \\
\hline Wyoming & $\mathrm{x}$ & 1500 & $\mathrm{x}$ & 10500 \\
\hline
\end{tabular}

Notes: Data come from Gallagher, et al. (1998); TANF Report to Congress (August 1998; May 2002). All dollar amounts are in current dollars.

${ }^{a}$ By the end of the 1998 fiscal year Ohio became the only state without a liquid asset limit. 


\section{Appendix Table A2: Full Specification for the Regression Results Reported in Table 3}

\begin{tabular}{|c|c|c|c|c|}
\hline Variable & $\begin{array}{l}\text { Panel A } \\
\text { Column I }\end{array}$ & $\begin{array}{l}\text { Panel A } \\
\text { Column II }\end{array}$ & $\begin{array}{l}\text { Panel B } \\
\text { Column I }\end{array}$ & $\begin{array}{l}\text { Panel B } \\
\text { Column II }\end{array}$ \\
\hline Change in State Asset Limit, 1994 - 2001 & $\begin{array}{l}2.49 e-5 \\
(7.76 e-6)\end{array}$ & $\begin{array}{l}2.46 \mathrm{e}-5 \\
(1.06 \mathrm{e}-5)\end{array}$ & $\begin{array}{l}0.082 \\
(0.044)\end{array}$ & $\begin{array}{l}0.037 \\
(0.054)\end{array}$ \\
\hline Female with Kids Asset Limit & $\begin{array}{l}-2.02 e-5 \\
(2.53 e-5)\end{array}$ & $\begin{array}{l}-1.64 e-5 \\
(2.60 e-5)\end{array}$ & $\begin{array}{l}-0.073 \\
(0.100)\end{array}$ & $\begin{array}{l}0.009 \\
(0.129)\end{array}$ \\
\hline Liquid Assets in 1994 & $\begin{array}{l}-1.15 e-5 \\
(2.45 e-6)\end{array}$ & $\begin{array}{l}-7.41 \mathrm{e}-7 \\
(3.52 \mathrm{e}-7)\end{array}$ & $\begin{array}{l}-0.951 \\
(0.004)\end{array}$ & $\begin{array}{l}-0.994 \\
(0.002)\end{array}$ \\
\hline Dummy: Female Head with Kids & $\begin{array}{l}0.021 \\
(0.037)\end{array}$ & $\begin{array}{l}-0.026 \\
(0.035)\end{array}$ & $\begin{array}{l}124.666 \\
(136.730)\end{array}$ & $\begin{array}{l}133.707 \\
(172.261)\end{array}$ \\
\hline Dummy: Age of Head between 30 and 39 & $\begin{array}{l}-0.060 \\
(0.039)\end{array}$ & $\begin{array}{l}-0.086 \\
(0.037)\end{array}$ & $\begin{array}{l}-220.662 \\
(87.100)\end{array}$ & $\begin{array}{l}-156.684 \\
(109.397)\end{array}$ \\
\hline Dummy: Age of Head between 40 And 45 & $\begin{array}{l}-0.003 \\
(0.041)\end{array}$ & $\begin{array}{l}-0.090 \\
(0.048)\end{array}$ & $\begin{array}{l}-69.955 \\
(111.545)\end{array}$ & $\begin{array}{l}65.064 \\
(138.059)\end{array}$ \\
\hline Dummy: Black Household Head & $\begin{array}{l}-0.125 \\
(0.029)\end{array}$ & $\begin{array}{l}-0.123 \\
(0.029)\end{array}$ & $\begin{array}{l}-296.550 \\
(79.404)\end{array}$ & $\begin{array}{l}-446.263 \\
(98.473)\end{array}$ \\
\hline Household Size & $\begin{array}{l}-0.006 \\
(0.009)\end{array}$ & $\begin{array}{l}0.002 \\
(0.008)\end{array}$ & $\begin{array}{l}-51.005 \\
(26.936)\end{array}$ & $\begin{array}{l}-40.983 \\
(33.350)\end{array}$ \\
\hline Change in Household Size, 1994 - 2001 & $\begin{array}{l}-0.003 \\
(0.011)\end{array}$ & $\begin{array}{l}0.004 \\
(0.011)\end{array}$ & $\begin{array}{l}-24.280 \\
(29.366)\end{array}$ & $\begin{array}{l}-14.889 \\
(36.132)\end{array}$ \\
\hline Average Household Labor Income (1994 - 2001) & $\begin{array}{l}7.61 e-6 \\
(1.68 e-6)\end{array}$ & $\begin{array}{l}2.49 \mathrm{e}-6 \\
(8.48 \mathrm{e}-7)\end{array}$ & $\begin{array}{l}-0.016 \\
(0.004)\end{array}$ & $\begin{array}{l}0.019 \\
(0.004)\end{array}$ \\
\hline Average Household Labor Income Squared & $\begin{array}{l}-4.19 e-11 \\
(1.55 e-11)\end{array}$ & $\begin{array}{l}-6.79 e-12 \\
(4.44 e-12)\end{array}$ & $\begin{array}{l}6.80 e-7 \\
(3.13 e-8)\end{array}$ & $\begin{array}{l}1.97 \mathrm{e}-7 \\
(2.81 \mathrm{e}-8)\end{array}$ \\
\hline Change in Household Income, $1994-2001$ & $\begin{array}{l}2.01 \mathrm{e}-6 \\
(5.27 \mathrm{e}-7)\end{array}$ & $\begin{array}{l}2.02 \mathrm{e}-6 \\
(4.92 \mathrm{e}-7)\end{array}$ & $\begin{array}{l}0.008 \\
(0.001)\end{array}$ & $\begin{array}{l}0.010 \\
(0.002)\end{array}$ \\
\hline State GDP per Capita in 1994 & $\begin{array}{l}-0.045 \\
(0.010)\end{array}$ & $\begin{array}{l}-0.048 \\
(0.010)\end{array}$ & $\begin{array}{l}-74.086 \\
(90.647)\end{array}$ & $\begin{array}{l}-91.684 \\
(118.94)\end{array}$ \\
\hline Change in State Unemployment Rate (1994 - 2001) & $\begin{array}{l}0.011 \\
(0.006)\end{array}$ & $\begin{array}{l}0.006 \\
(0.005)\end{array}$ & $\begin{array}{l}-10.446 \\
(23.045)\end{array}$ & $\begin{array}{l}12.061 \\
(27.686)\end{array}$ \\
\hline Dummy: Household Head has Education $=12$ & $\begin{array}{l}0.062 \\
(0.036)\end{array}$ & $\begin{array}{l}0.056 \\
(0.033)\end{array}$ & $\begin{array}{l}198.455 \\
(100.133)\end{array}$ & $\begin{array}{l}188.219 \\
(126.901)\end{array}$ \\
\hline Dummy: Household Head has Education $>12$ & $\begin{array}{l}0.084 \\
(0.039)\end{array}$ & $\begin{array}{l}0.078 \\
(0.037)\end{array}$ & $\begin{array}{l}310.415 \\
(111.663)\end{array}$ & $\begin{array}{l}391.493 \\
(139.305)\end{array}$ \\
\hline Constant & $\begin{array}{l}0.346 \\
(0.053)\end{array}$ & $\begin{array}{l}0.424 \\
(0.041)\end{array}$ & $\begin{array}{l}509.828 \\
164.848\end{array}$ & $\begin{array}{l}359.452 \\
(203.190)\end{array}$ \\
\hline
\end{tabular}

Notes: Data is from the Panel Study of Income Dynamics. See footnote to Table 3 for full sample description. Dependent variable in Panel A is a dummy variable equal to 1 if the household had positive liquid saving between 1994 and 2001, and in Panel B is the change in liquid assets between 1994 and 2001. All level variables are measures as of 1994. All change variables are measured as the change between 1994 and 2001. 
Appendix Table A3. State Termination Time Limits as of Fiscal Year 2001

\begin{tabular}{|c|c|c|}
\hline State & Limit Less Than Federal Maximum & Number of Months \\
\hline \multicolumn{3}{|l|}{ Alabama } \\
\hline \multicolumn{3}{|l|}{ Alaska } \\
\hline \multicolumn{3}{|l|}{ Arizona } \\
\hline Arkansas & $\mathrm{x}$ & 24 \\
\hline \multicolumn{3}{|l|}{ California } \\
\hline \multicolumn{3}{|l|}{ Colorado } \\
\hline Connecticut & $\mathrm{x}$ & 21 \\
\hline Delaware & $\mathrm{x}$ & 48 \\
\hline \multicolumn{3}{|c|}{ District of Columbia } \\
\hline Florida & $\mathrm{x}$ & 24 out of 60 \\
\hline Georgia & $\mathrm{x}$ & 48 \\
\hline \multicolumn{3}{|l|}{ Hawaii } \\
\hline Idaho & $\mathrm{x}$ & 24 \\
\hline Illinois & $\mathrm{x}$ & 24 \\
\hline \multicolumn{3}{|l|}{ Indiana } \\
\hline \multicolumn{3}{|l|}{ Iowa } \\
\hline \multicolumn{3}{|l|}{ Kansas } \\
\hline \multicolumn{3}{|l|}{ Kentucky } \\
\hline Louisiana & $\mathrm{x}$ & 24 out of 60 \\
\hline \multicolumn{3}{|l|}{ Maine } \\
\hline \multicolumn{3}{|l|}{ Maryland } \\
\hline Massachusetts & $\mathrm{x}$ & 24 out of 60 \\
\hline \multicolumn{3}{|l|}{ Michigan } \\
\hline \multicolumn{3}{|l|}{ Minnesota } \\
\hline \multicolumn{3}{|l|}{ Mississippi } \\
\hline \multicolumn{3}{|l|}{ Missouri } \\
\hline \multicolumn{3}{|l|}{ Montana } \\
\hline Nebraska & $\mathrm{x}$ & 24 out of 48 \\
\hline Nevada & $\mathrm{x}$ & 24 \\
\hline \multicolumn{3}{|l|}{ New Hampshire } \\
\hline \multicolumn{3}{|l|}{ New Jersey } \\
\hline New Mexico & $\mathrm{x}$ & 36 \\
\hline \multicolumn{3}{|l|}{ New York } \\
\hline North Carolina & $\mathrm{x}$ & 24 out of 60 \\
\hline \multicolumn{3}{|l|}{ North Dakota } \\
\hline Ohio & $\mathrm{x}$ & 36 \\
\hline Oklahoma & & \\
\hline Oregon & $\mathrm{x}$ & 24 out of 84 \\
\hline Pennsylvania & & \\
\hline Rhode Island & & \\
\hline South Carolina & $\mathrm{x}$ & 24 out of 120 \\
\hline South Dakota & & \\
\hline Tennessee & $\mathrm{x}$ & 18 \\
\hline Texas & & \\
\hline Utah & $\mathrm{x}$ & 36 \\
\hline Vermont & & \\
\hline Virginia & $\mathrm{x}$ & 24 \\
\hline Washington & & \\
\hline West Virginia & & \\
\hline Wisconsin & & \\
\hline Wyoming & & \\
\hline
\end{tabular}




\section{Appendix Table A4: Maximum State AFDC/TANF Benefits for a Family of Three}

\begin{tabular}{|c|c|c|}
\hline State & 1994 & 2001 \\
\hline Alabama & $\$ 164$ & $\$ 164$ \\
\hline Alaska & 923 & 923 \\
\hline Arizona & 347 & 347 \\
\hline Arkansas & 204 & 204 \\
\hline California & 607 & 645 \\
\hline Colorado & 356 & 356 \\
\hline Connecticut & 680 & 581 \\
\hline Delaware & 338 & 338 \\
\hline District of Columbia & 420 & 379 \\
\hline Florida & 303 & 303 \\
\hline Georgia & 280 & 280 \\
\hline Hawaii & 712 & 712 \\
\hline Idaho & 317 & 293 \\
\hline Illinois & 367 & 377 \\
\hline Indiana & 288 & 288 \\
\hline Iowa & 426 & 426 \\
\hline Kansas & 429 & 386 \\
\hline Kentucky & 228 & 262 \\
\hline Louisiana & 190 & 240 \\
\hline Maine & 418 & 461 \\
\hline Maryland & 366 & 439 \\
\hline Massachusetts & 579 & 633 \\
\hline Michigan & 459 & 459 \\
\hline Minnesota & 532 & 536 \\
\hline Mississippi & 120 & 170 \\
\hline Missouri & 292 & 292 \\
\hline Montana & 401 & 494 \\
\hline Nebraska & 364 & 364 \\
\hline Nevada & 348 & 348 \\
\hline New Hampshire & 550 & 600 \\
\hline New Jersey & 424 & 424 \\
\hline New Mexico & 357 & 439 \\
\hline New York & 577 & 577 \\
\hline North Carolina & 272 & 266 \\
\hline North Dakota & 409 & 457 \\
\hline Ohio & 341 & 373 \\
\hline Oklahoma & 324 & 292 \\
\hline Oregon & 460 & 460 \\
\hline Pennsylvania & 421 & 403 \\
\hline Rhode Island & 554 & 554 \\
\hline South Carolina & 200 & 203 \\
\hline South Dakota & 417 & 430 \\
\hline Tennessee & 185 & 185 \\
\hline Texas & 184 & 201 \\
\hline Utah & 414 & 451 \\
\hline Vermont & 638 & 629 \\
\hline Virginia & 354 & 320 \\
\hline Washington & 546 & 546 \\
\hline West Virginia & 249 & 453 \\
\hline Wisconsin & 517 & 673 \\
\hline Wyoming & 360 & 340 \\
\hline
\end{tabular}

Source: 1994 Green Book and Congressional Research Service Report 98-480.

All dollar amounts are in current dollars. 